\title{
EFEITO DE RECIPIENTES E SUBSTRATOS NO COMPORTAMENTO SILVICULTURAL DE PLANTAS DE Eucalyptus grandis. HILL EX MAIDEN E DO Eucalyptus urophylea S.T. BLAKE
}

\author{
ANTONIO CARLOS GESTA DE MELO \\ Engenheiro Florestal
}

Orientador: Prof. Dr: JOÃO WALTER SIMÕES

Dissertação apresentada à Escola Superior de Agricultura "Luiz de Queiroz", da Universidade de São Paulo, para a obtenção do título de Mestre em Ciências Florestais.

P I R A C I C A B A

Estado de São Paulo - Brasil

Novembro - 1989 
Ficha catalográfica preparada pela Seção de Livros da Divisão de Biblioteca e Documentação - PCAP/USP

M528e

Melo, Antonio Carlos Gesta de Efeito de recipiente e substrato no comportamen to silvicultural de plantas de Eucalyptus grandis Hill ex Maiden e do Eucalyptus urophylla S.T. Blake. Piracicaba, 1989.

$80 \mathrm{p}$. ilus.

Diss.(Mestre) - ESALQ

Bib1iografia.

1. Eucalípto - Muda - Comportamento 2. Eucalípto Muda - Crescimento 3. Eucalípto - Muda - Efeito de recipiente 4. Eucalípto - Muda - Efeito de substrato 5. Muda - Comportamento I. Escola Superior de Agricultura Luiz de Queiroz, Piracicaba 
EFETTO DE RECIPIENTES E SUBSTRATOS NO COMPORTAMENTO SILVICULTURAL DE PLANTAS DE Eucalyptus grandis HILL EX MAIDEN E DO Eucalyptus urophylla S.T. BLAKE

Aprovada em: 05/12/89

Comissão julgadora:

Prof. Dr. João Walter Simões

ESALQ/USP

Prof. Dr. Mário Tomazello Filho ESALQ/USP

prof. Dr. José Dias Costa

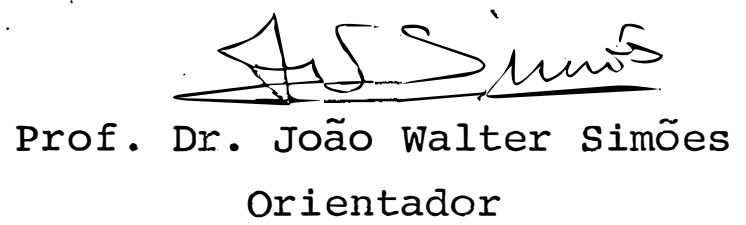


.iie.

A minha esposa Ana Maria e aos meus filhos Antonio Carlos, Ma kysa e Thiago,

DEDICO

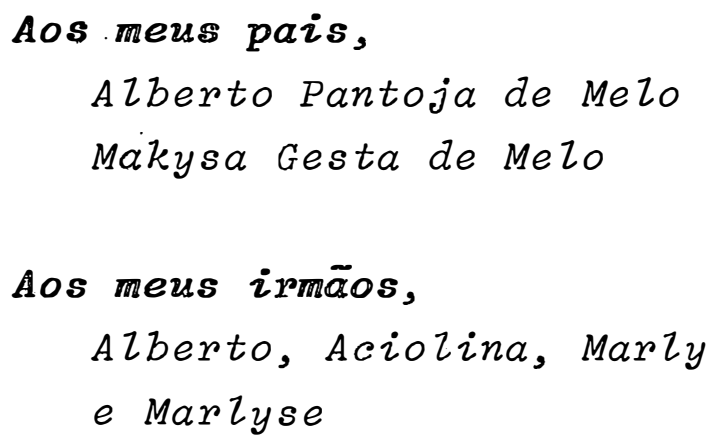




\section{AGRADECIMENTOS}

Os meus sinceros agradecimentos às pessoas e instituições que contribuíram para a realização do trabalho, com especial referência:

Ao Prof. Dr. João Walter Simões, pela orientação, amizade e atẹção dispensada na realização deste trabalho e durante o Curso de Pós-Graduação;

A CEPLAC - Comissão Executiva do Plano da Lavoura Cacaueira, pela oportunidade da realização do Curso de Pós-Graduação;

A RIPASA S/A CELULOSE E PAPEL, na pessoa do Eng Ftal. José Luiz Stape, pelo apoio e colaboração prestados na realiza ção deste trabalho;

Ao Prof. Dr. Hilton Thadeu Zarate do Couto, pelo apoio e orientação referente às análises estatísticas;

Ao técnico em computação Milton Cezar Ribeiro;

Aos Docentes do:Departamento de Ciências Florestais, da EscoSuperior de Agricultura "Luiz de Queiroz", da Universidade de São Paulo, pelos ensinamentos recebidos;

Aos funcionários do Departamento de Ciências Florestais pela atenção e boa convivência;

A Engå Agrá Silvia Regina c. Stipp, pela colaboração na revisão do trabalho, e ao Enge Ftal. Jaime T. França pelas fotografias ;

Aos colégas de Pós-Graduação pela amizade e boa convivência;

A CAPES, pela bolsa de estudo concedida durante a fase de elaboração da Dissertação. 
LISTA DE TABELAS $\ldots \ldots \ldots \ldots \ldots \ldots \ldots \ldots \ldots \ldots \ldots \ldots \ldots \ldots \ldots$

LISTA DE FIGURAS $\ldots \ldots \ldots \ldots \ldots \ldots \ldots \ldots \ldots \ldots$

RESUMO

xii

SUMMARY

xiv

1. INTRODUÇÃO $\ldots \ldots \ldots \ldots \ldots \ldots \ldots \ldots \ldots \ldots \ldots \ldots \ldots \ldots \ldots \ldots$

2. REVISÃO DE LITERATURA $\ldots \ldots \ldots \ldots \ldots \ldots \ldots \ldots \ldots$

2.1. Substratos ..................... 4

2.2. Uso de recipientes ................ 7

2.3. Tamanho de mudas e o desempenho no campo ... 10

2.4. Crescimento de raízes .............. 14 .

3. MATERIAL E MÉTODOS $\ldots \ldots \ldots \ldots \ldots \ldots \ldots \ldots \ldots \ldots \ldots \ldots$

3.1. Espécies e obtenção de sementes .......... 17 .

3.2. Recipientes ................... 17

3.2.1. Tubetes de polietileno ("dibble tube" ) .................... 17

3.2.2. Saco plástico $\ldots \ldots \ldots \ldots \ldots \ldots \ldots \ldots 18$

3.3. Substratos utilizados $\ldots \ldots \ldots \ldots \ldots \ldots \ldots \ldots . . \ldots$

3.4. Local do experimento .............. 22

3.4.1. Clima e solo .................. 22 .

3.5. Delineamento experimental ............... 25

3.6. Instalação do experimento ............ 28

3.6.1. Preparo do solo e adubação ........ 28

3.6.2. Plantio e tratos culturais ........ 28. 
.vi.

Pågina

3.7. Avaliação do experimento $\ldots \ldots \ldots \ldots \ldots \ldots . . \ldots 29$

3.8. Morfologia das raizes .............. 30 *

4. RESULTADOS E DISCUSSÃO 32

4.1. Comportamento das plantas no campo ........ $32^{\circ}$

32

4.1.1. Avaliação aos 6 meses de idade ..... 32

4.1.2. Avaliação aos 13 meses de idade .... 32

4.1.3. Avaliação aos 37 meses de idade .... 45

4.2. Descrição das raızes ................ 54 •

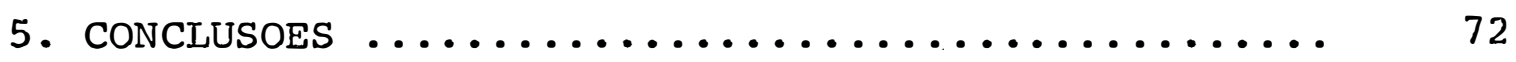

REFERENCIAS BIBLIOGRÁFICAS $\ldots \ldots \ldots \ldots \ldots \ldots \ldots \ldots \ldots$ 


\section{LISTA DE TABELAS}

Página

Tabela ne

1 Características físicas e químicas do composto

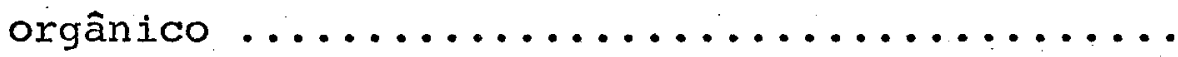

2 Quantidade de fertilizates utilizados por $1 \mathrm{~m}^{2}$ de composto $\ldots \ldots \ldots \ldots \ldots \ldots \ldots \ldots \ldots \ldots$

3 Dados climatológicos (precipitação e temperatŭ ra) locais durante o periodo experimental ....

4 Resultado da análise de solo............. 26

5 Tratamentos aplicados no ensaio........... 27

6. Altura e DAP das árvores selecionadas em fun ção do recipiente e dos estratos de altura das das árvores, aos 39 meses de idade ...........

7 Crescimento em altura e sobrevivência (folhas, plantas mortas e vivas) de Eucalyptus, nos diferentes tratamentos aos 6 meses de idade ....

8 Resultados das análises de variância de altura e de sobrevivência, com dados percentuais trans formados em arc sen $\sqrt{\mathrm{x} / 100}$, de Eucalyptus aos

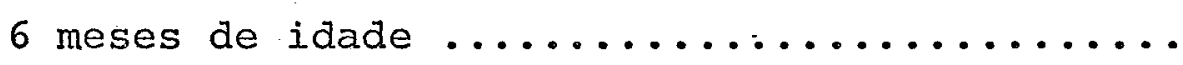

9 Desdobramento dos graus de liberdade para altu ra $(m)$ entre espécie aos 6 meses de idade .... 
pāgina

Tabela no

10 Crescimento em altura e sobrevivência (falhas, plantas mortas e vivas), de Eucalyptus, nos dî ferentes tratamentos, aos 13 meses de idade..

11 Resultados das análises de variância de altura e de sobrevivência, com dados percentuais trans formados em arc sen $\sqrt{x / 100}$, de Eucalyptus aos

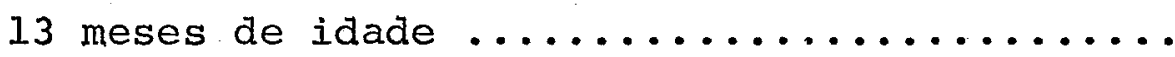

12 Desdobramento dos graus de liberdade, para altura (m) entre espécie, aos 13 meses de ida-

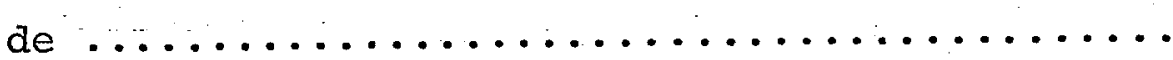

13 Análise de variância da altura, diâmetro à altura do peito (DAP), área basal, volume cilinarico, bifurcação e plantas mortas, transforma das em arc sen $\sqrt{x / 100}$, de Eucalyptus nos diferentes tratamentos, aos 37 meses de idade....

14 Resultados do desdobramento dos graus de liber dade para altura, DAP, área basal, volume ciIindrico, bifurcação e plantas mortas, com per centuais transformados em arc sen $\sqrt{x / 100}$, de Eucalyptus aos 37 meses de idade ........... 


\section{LISTA DE FIGURAS}

Página

Figura no

1 Balanço hîdrico mensal, segundo THORNTHWHITE \& MATHER (1955), para a Fazenda Flexa Azul, em Boa Esperança do Sul-SP, baseado em dados termo-pluviométricos no período de 1986 - março/

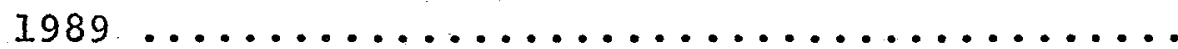

2 Altura média das espécies de eucalipto nos diferentes tratamentos aos 6 meses de idade ....

3 Altura média das espécies de eucalipto aos 6

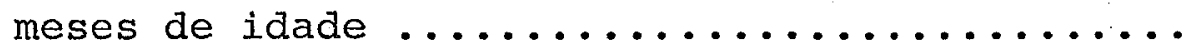

4 Altura média das espécies de eucalipto nos diferentes tratamentos, aos 13 meses de idade ..

5 Altura média das espécies de eucalipto, aos 13

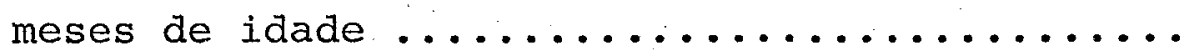

6 Altura média das espécies de eucalipto nos diferentes tratamentos aos 13 meses de idade ...

7. Altura e DAP médios das espécies de eucalipto,

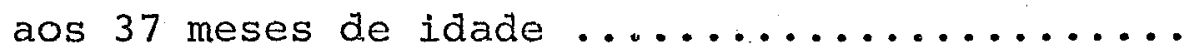

8 Área basal e volume cilinndrico médios das espé cies de eucalipto aos 37 meses de idade .....

9 Raizes de árvore dominante de Eucalyptus grandis, aos 39 meses de idade, oriunda de muda

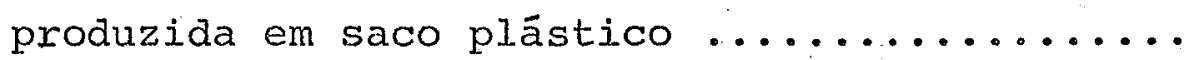


10 Raízes de árvore dominante de Eucalyptus gran dis, aos 39 meses de idade, oriunda de muda produzida em tubete .................

11. Raízes de árvore média de Eucalyptud grandis, aos 39 meses de idade, oriunda de muda produ-

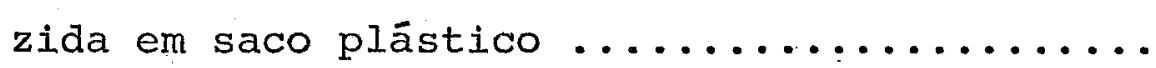

12 Raízes de ārvore média de Eucalyptus grandis, aos 39 meses de idade, oriunda de muda produ-

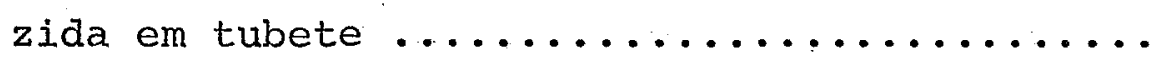

13 Raízes de ārvore dominada de Eucalyptus grandis aos 39 meses de idade, oriunda de muda

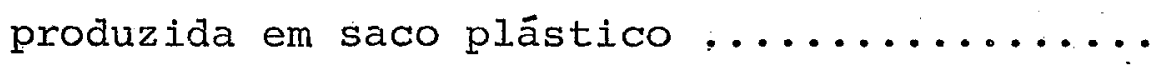

14 Raizes de árvore dominada de Eucalyptus grandis aos 39 meses de idade, oriunda de muda

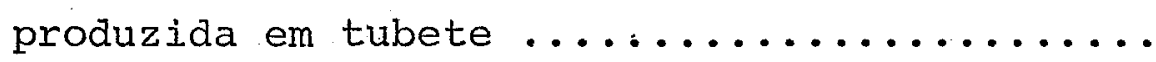

15. Raizes de árvore morta de Eucalyptus grandis, aos 39 meses de idade, oriunda de muda produzida em saco plástico .................

16 Raizes de ärvore morta de Eucalyptus grandis, aos 39 meses de idade, oriunda de muda produ-

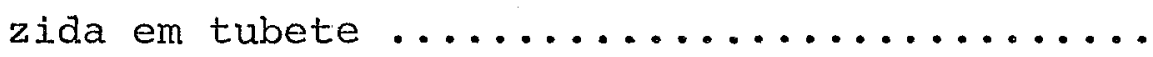

17 Raizes de árvore dominante de Eucalyptus urophylla, aos 39 meses de idade, oriunda de muda produzida em saco plástico ............ 
Figura no

18 Raízes de árvore dominante de Eucalyptus uro phylla, aos 39 meses de idade, oriunda de muda produzida em tubete..$\ldots \ldots \ldots \ldots \ldots \ldots$

19 Raízes de árvore média de Eucalyptus urophylla, aos 39 meses de idade, oriunda de muda produ-

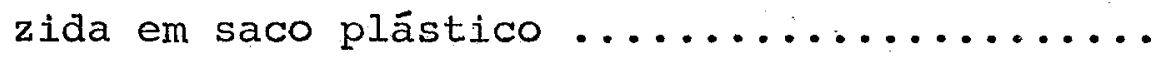

20 Raízes de árvore média de Eucalyptus urophylla, aos 39 meses de idade, oriunda de muda produzida em tubete $. \ldots \ldots \ldots \ldots \ldots \ldots \ldots \ldots \ldots . . \ldots \ldots$

21 Raízes de árvore dominada de Eucalyptus urophylla, aos 39 meses de idade, oriunda de mu-

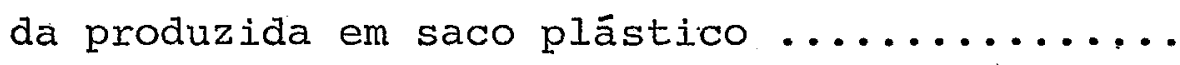

22 Raízes de árvore dominada de Eucalyptus urophylla, aos 39 meses de idade, oriunda de muda produzida em tubete $\ldots \ldots \ldots \ldots \ldots \ldots \ldots$

23 Raízes de ārvore morta de Eucalyptus urophylla, aos 39 meses de idade, oriunda de muda produ-

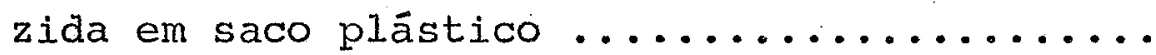

24 Raízes de árvore morta de Eucalyptus urophylla, aos 39 meses de idade, oriunda de muda produzida em tubete $\ldots \ldots \ldots \ldots \ldots \ldots \ldots \ldots \ldots$ 
EFE ITO DE RECIPIENTE E SUBSTRATO NO COMPORTAMENTO SILVICULTURAL DE PLANTAS DE Eucalyptus grandis HILL EX MAIDEN E DO Eucalyptus urophylla S.T. BLAKE

Autor: ANTONIO CARLOS GESTA DE MELO Orientador: Prof. Dr. JOÃO WALTER SIMÕES

\section{RESUMO}

o objetivo deste trabalho foi avaliar o desenvolvimento de mudas de Eucalyptus grandis e de Eucalyptus uro phylla no campo, produzidas em diferentes recipientes, substratos e com alturas e idades distintas, como tambëm observar a morfologia de suas raízes, aos 39 meses de idade, face a va riação de altura e de recipientes.

o experimento foi instalado em fevereiro de 1986, em uma área do Parque Florestal Flexa Azul, da Ripasa S/A Papel e Celulose, localizada no município de Boa EsperanÇa do Sul-SP, obedecendo um delineamento em blocos ao acaso, com esquema fatorial, com três repetições.

As avaliações foram realizadas aos 6 e 13 meses de idade, coletando-se dados de altura total, falhas, plantas mortas e vivas, e aos 37 meses de idade acrescentou-se, às 
variáveis mencionadas, O DAP (diâmetro à altura do peito), a área basal, o volume cilíndrico e a bifurcação. Aos 39 meses de idade observou-se a morfologia das raizes laterais.

As principais conclusões obtidas foram: a) as variações de tipos de substratos, recipientes e de tamnho e idade das mudas, por ocasião do plantio, não revelaram efeitos diferenciados sobre o crescimento e sobrevivências das plantas; b) apesar da menor capacidade de sobrevivência do Eucalyptus grandis, o mesmo apresentou um volume cilíndrico de $202,39 \mathrm{~m}^{3} / \mathrm{ha}$, enquanto que o Eucalyptus urophylla apresentou $164,17 \mathrm{~m}^{3} /$ ha e mostrou ser uma espécie de maior rusticida de, aos 37 meses de idade; c) não houve diferenças nitidas e preponderantes nas raízes, em função dos tipos de recipientes; d) a posição competitiva das árvores, mostrou ter maior influência sobre a morfologia dos sistemas radiculares. 
EFFECTS OF DIFFERENT CONTAINERS AND SUBSTRATS IN THE. SILVICULTURAL BEHAVIOR OF Eucalyptus grandis HILL EX MAIDEN AND Eucalyptus urophylla S.T. BLAKE TREES.

Author: AN'TONIO CARLOS GESTA DE MELO Adviser: Prof. Dr. JOÃO WALTER SIMÕES

\section{SUPMARY}

The aim of this work was to evaluate the deve lopment of seedlings of Eucalyptus grandis and Eucalyptus urophylla in the field produced in different containers and substrats and of different heights and ages, as well as to study the morphology of their roots at 39 monts of age.

The experiment was set up in February 1986 in area of the Parque Florestal Flexa Azul, belonging to Ripasa S/A Papel e Celulose, in the coutry of Boa Esperança do Sul, State of são paulo. The experiment followed a factorial ran domized block design with three replications.

The evaluation were made at 6 and 13 months of age by collecting data concerning to total height, failures dead and live plants, and at 37 months of age, adding to the parameters mentioned above the DBH, basal area, cylinarical 
volume and bifurcation. At 39 months of age the morphology of lateral roots was observed. The main conclusions are: a) variation in the kinds, of substrat, and containers, and in the size and age of the seedlings time at planting did not show any distinct effect on growth and survival of plants; b) even through Eucalyptus grandis showed less capacity to survice, this species shoed a productivity of $202.39 \mathrm{~m}^{3} /$ ha while, Eucalyptus urophylla showed $164.17 \mathrm{~m}^{3} / \mathrm{ha}$ and the most resistant species to water stress at 37 months after plants; c) there was no clear difference of the roots in relation to the kinds of containers; d) the competitive position of the trees showed to have a greater influence on the morphology of the root systems. 


\section{INTRODUCÃO}

O aumento do consumo de produtos florestais, tem como conseqüência a necessidade de se introduzir nos pro gramas de florestamento ou reflorestamento no Brasil, espécies de alta produtividade que permitam um ciclo de corte relativamente curto, associada às boas caracteristicas silviculturais. Dentre as espécies nativas e exóticas, as que melhor a1cançaram esses objetivos foram as pertencentes ao gênero Eucalyptus.

o Eucalyptus grandis Hill ex Maiden, constituise na espécie mais utilizada nos reflorestamentos no Brasil. Destaca-se pelo seu rápido crescimento, boa adaptação e res posta à tecnologia silvicultural, associada à grande diversidade de utilização de sua madeira (matéria-prima inaustrial, combustível lenhoso e de outros produtos para consumo domésti co).

Nos ültimos anos, o Eucalyptus urophylla S. T. Blake vem sendo bastante utilizado nos programas de reflorestamento. Destaca-sé pelo fato de apresentar maior rustici 
dade, boa resistência a pragas e doenças, altos incrementos volumétricos anuais, aliados à boa aceitação como matēria-pri ma para as fábricas de celulose e papel, chapas duras e moles, etc.

A utilização de técnicas inadequadas para a produção de mudas de essências florestais pode prejudicar todo um programa de reflorestamento.

A muda, como produto final do trabalho do viveiro, traz consigo caracteristicas distintas, visto que, a manutenção e melhoria do sistema de produção determinam todo - dinamismo do viveiro florestal, justificando uma busca cons tante de inovações têcnicas para obter melhor qualidade da mu da.

Necessārio se faz ter em mente que a avaliação da muda não se encerra no momento em que ela sai do viveiro. E preciso a verificação de seu comportamento no campo, atē a obtenção do produto final.

A seleção de mudas em viveiro é uma questão bastante controvertida, visto que, alguns autores mencionam que num plantio efetuado sem uma seleção prévia das mudas, apōs um determinado tempo, as plantas se igualam em altura, e a floresta passa a apresentar um desenvolvimento mais homogêneo. Outros autores citam que a seleção de mudas maiores dão origem a árvores de maior porte.

Por outro lado, é importante mencionar que a 
produção em si da muda em um viveiro, não aumenta a capacidade produtiva do material genético disponivel, mas certamente pode comprometer seriamente a produtividade, a qualidade do produto e o custo de produção da madeira.

O conhecimento da configuração radicular no campo é relevante para se determinar os efeitos que diferentes formas radiculares têm sobre o crescimento e estabilidade de árvores plantadas.

Os efeitos de raízes mal-formadas não podem ser reparados após o plantio da muda, mas algumas práticas silviculturais podem ser usadas para minimizar esse problema.

Dentre as muitas variáveis na produção de mudas, é de grande importância para a determinação de sua quali dade e seus reflexos no campo, a embalagem, o substrato, idade e a altura da muda.

Este trabalho teve como objetivos:

a) Avaliar o desenvolvimento das mudas de Eucalyptus grandis Hill ex Maiden e Eucalyptus urophylla S. T. Blake no campo, produzidas em diferentes recipientes, substra tos e com alturas e idades distintas.

b) Observar a morfologia das raizes laterais das espëcies estudadas, aos 39 meses de campo, face a variação de altura da:árvore e de recipientes. 


\section{REVISÃO DE LITERATURA}

\subsection{Substratos}

o substrato exerce uma influência significativa na arquitetura do sistema radicular, no estado nutricional das plantas (SPURR \& BARNES, 1973), assim como na translo cação de ãgua no sistema solo-planta-atmosfera (ORLANDER \& DUE, 1986).

o substrato, segundo uma versão do ideal, deve ser de baixa densidade, rico em nutrientes, ter uma composição química e física uniforme, elevada capacidade de troca catiônica, boa capacidade de retenção de água, aeração e drenagem, boa coesão entre as partículas ou aderência junto às raízes e ser preferencialmente um meio estéril (COUTINHO \& CARVALHO, 1983).

A fração argilla dá ao solo propriedades de plastịcidade e pegajosidade e, junto com a matēria orgâni ca, proporciona a fração dinâmica do solo, pois apresenta alta capacidade de absorção de água, gases e sais minerais, 
cedendo às plantas parte da água e dos nutrientes (MONIz, 1972)

Segundo PONS (1983) as fontes mais comuns de matéria orgânica que contém macro e micronutrientes são os adubos orgânicos. Para os adubos orgânicos não se deve levar em consideração somente o conteúdo de nutrientes, mas também seu efeito sobre o solo ou substrato como: processos microbia nos, aeração, estrutura e capacidade de retenção de água e a regulação da temperatura do meio.

BOON \& NIERS (1985) testaram casca de coniferas (como composto ou não) e mistura de turfa com cavacos de madeira aquecidos, contra um substrato padrão constituído de turfa mais areia, para a produção de mudas de espēcies arbóreas de clima temperado. Observaram que somente com a aplica ção de nitrogênio os substratos proporcionaram bom crescimen to às mudas comparativamente ao substrato padrão.

STAPE \& BALLONI (1987), testando vārios substratos em tubete para produção de mudas de Eucalyptus, encontraram melhores resultados em casca de eucalipto compostada com adubação líquida.

AGUIAR \& MONOGIOS (1988) estudando :substratos à base de vermiculita, para produção de mudas de Eucalyptus citriodora Hook, em bandejas de isopor, observaram um péssimo estado de agregação entre o sistema radiculare o substrato e, 
que a poda das raízes pelo ar, característica desses sistema de produção de mudas, não promoveu o desenvolvimento de raïzes nessa espēcie.

CAMPINHOS JR. et alii (1984) testando turfa, vermiculita, serragem e suas combinações como meio de crescimento de mudas de Eucalyptus (sementes e estacas) e Pinus (se mentes) em tubetes, concluíram que o meio obtido com a mistura entre turfa e vermiculita na proporção de $2: 1$, foi 0 meIhor para mudas de sementes. Para estacas, o melhor resultado foi obtido com vermiculita pura.

WALTERS \& HORIUCHI (1979) citam que a mistura de esfagno e vermiculita, na proporção de 1:1, é um meio de crescimento, que propicia um bom desenvolvimento para mudas de Eucalyptus saligna no Havai, utilizado no sistema "dibbling tube".

SKOLMEN \& GOO (19986) estudando o efeito de 11 diferentes substratos na germinação e crescimento de mudas de Eucalyptus saligna, em Honolulu, encontraram na turfa + vermi culita $(2: 1)$ o melhor tratamento:

FERNANDES et alii (1982) observaram que a vermiculita provocou um efeito favorável. a retirada das mudas de Eucalyptus saligna, em sistemas de bandejas de isopor, tendo como base, para a composição do meio de crescimento, ter ra de subsolo sílicomargilosa. 
NOEARI et alii (1984) relataram a necessidade da adição de adubos orgânicos, adequadamente decompostos, à mistura utilizada como substrato (solo arenoso + solo argiloso) para a formação de mudas de Schizolobium parahyba (Veloso) Blake.

MARQUES \& YARED (1984) encontraram como substrato mais adequado para produção de mudas de Didymopanax morototoni (Aublet.) Decne a mistura: 60\% de Latossolo Amarelo + 20\% areia + 20\% matéria orgânica e, citam ainda, que o tempo de formação das mudas foi reduzido de dez para seis meses.

\subsection{USO DE RECIPIEMTES}

SIMÕES (1987) relata que o sistema de mudas em baladas é o maịs indicado para regiões tropicais. Embora mais caras, as mudas apresentam condição essencial para assegurar alto pegamento no plantio.

WALTERS (1981) comparando custo de plantio de mudas de Eucalyptus saligna no Havai, entre sistema de tubete e raiz nua, encontrou que mudas em sistema de tubete são mais caras para: produção e transporte. Porēm, no custo final do estabelecimento do plantio, o uso de tubetes resulta numa substancial economia. O mesmo autor, em 1970, cita que a taxa média de sobrevivência em sistema de tubete é de $91 \%$, enquanto que de raiz nua é de $56 \%$. 
ELAM \& KOELIING (1974) citam algumas funções biológicas do recipiente como: conter um substrato que propor ciona bom crescimento e nutrição das raizes; proteger as raízes de danos mecânicos e desidratação; promover boa formação do sistema radicular; garantir máxima sobrevivência no campo e bom crescimento inicial.

Nos últimos anos, mais de 20 recipientes têm sido testados para produção de mudas de essências florestais, é dentre esses, o que se destaca em termos de utilização são os sacos de polietileno e mais recentemente os tubetes de polietileno rígido ("dibble-tube") .

CAMPINHOS JR. \& IKEMORI (1983) citam que o recipjente mais usado no Brasil para produção de mudas de Eucalyptus e de outras essências florestais è o saco plástico, em bora sejam bem conhecidos os seus inconvenientes.como: espira lamento do sistema radicular, o que notadamente provoca um al to Indice de morte após o plantio; o substrato utilizado-tex ra - é muito densa, dificultando as operações de viveiro, transporte para o campo e distribuição no plantio. E necessário que a terra esteja seca; o enchimento é manual; há necessidạ de de se retirar a embalagem retardando a operação de plantio.

PARVIAINEN (1981) cita que a produção de mudas em recipientes de paredes internas lisas provocam enovelamento de raiz, podendo ser acertado com a formação de estrias longitudinais internas. 
SCHMIDT-VOGT (1984b) cita que a influência do recipiente é de suma importância, haja vista que o crescimen to em espiral das raízes continua na fase de campo e que pode proporcionar uma baixa estabilidade das futuras árvores.

AGUIAR (1973) estudando a influência de recipientes no comportamento de Eucalyptus grandis e Eucalyptus saligná após o plantio, verificou que a alta sobrevivência das mudas no campo foi devida às vantajosas condições de plan tio, não constatando diferenças entre eles.

FAGUNDES \& FIALHO (1987) citam algumas vantagens técnicas do sistema de tubete como: formação do sistema radicular sem enovelamento e crescimento inicial mais rápido, logo após o plantio. Citam ainda facilidades operacionais co mo: trabalha-se com qualquer condição climática, o que permite cumprir o cronograma de produção; o transporte das mudas por caminhão é 5 a 6 vezes maior que o sistema de saco plástí co e no peso 2 a 2,5 vezes menor, e o rendimento de plantio é 3 vezes maior. 


\subsection{TAMANHO DE MUDAS E O DESEMPENHO NO CAMPO}

Em vários países a classificação de mudas têm como base os parâmetros morfológicos, muito embora os efeitos das características internas, denominadas fisiológicas, sejam tão importantes como os parâmetros baseados nas caracteristí cas fenotípicas das mudas, denominadas morfológicas (SCHMIDTVOGT, 1984a; CARNEIRO, 1983).

As variáveis consideradas na classificação mor fológica das mudas são: a) diâmetro do colo; b) altura, c) relação entre diâmetro do colo e altura; d) relação entre altura da muda e raiz; e) peso seco e verde das partes aérea e subterrânea; f) peso seco total; g) rigidez da haste; $\mathbb{m}$ ) idade; muito embora nenhuma destas variáveis deva ser usada como critério único na classificação das mudas para plantio (SCHUBERT \& ADAMS, 1971; SCHMIDT-VOGT, 1984b; CARNEIRO， 1985).

As características morfológicas são tambëm influenciadas pelas características das espécies (SCHMIDT-VOGT, 1984). De acordo com os sistemas de produção ou técnicas empregadas, pode-se obter maior ou menor quantidade de mudas de boa qualidade, proporcionando uma maior ou menor sobrevivência após o plantio (CARNEIRO, 1976).

POLLARD (1974) cita que o tamanho da muda tem sido um importante critērio para um esquema de plantio, especialmente com mudas produzidas em recipientes, que afetam os 
custos em quase todos os estágios de operação no viveiro. E também, um fator crítico de sobrevivência e crescimento após - plantio.

BLAKE et alii (1988) constataram que as diferenças em tamanho de mudas de Eucalyptus existentes por ocasião do plantio, revelaram-se um indicador pobre do comportamento do crescimento, pois as espécies e as mudas pequenas ñão apresentaram diferenças aos. 15 meses: "

Ainda, POLLARD (1974) trabalhando com Picea glauca (Moench) mostrou que a influência do tamanho da muda sobre o potencial de crescimento no campo, diminuiu quando as mesmas eram mais velhas.

BRIGATTI (1983) estudando a influência que cin co classes de tamanho de mudas de Eucalyptus grandis exercem no campo, observou uma discreta tendência de aumento da al tura e do diâmetro da planta, em função de seu tamanho 'por ocasião do plantio, embora tais diferenças não tenham sido significativas.

MORAIS \& BRUNE (1983) estudando a correlação juvenil-adulta em Eucalyptus grandis, verificaram que o efeito inicial das mudas no viveiro (diferentes tamanhos) só acusa diferença significativa no primeiro ano e, que a competição até o terceiro ano não foi bastante pronunciada ao ponto de suprimir os tratamentos que estavam inferiores até $o$ ano anterior, visto que eles se igualaram. 
COELHO (1984) estudando o comportamento do Eucalyptus grandis, face a classificação pelo tamanho de semente, de plântula e de muda, observou que no decorrer de 12 meses a vantagem inicial para o tamanho de sementes e plântulas grandes não se manteve, porém a seleção de mudas ' de maior tamanho teve efeito altamente significativo sobre o crescimen to em altura e diâmetro.

LAUER (1987) estudando a influência do tamanho da muda no crescimento inicial de Pinus palustris Mill., observou que essa característica não influenciou significativa mente a sobrevivência, mas revelou um efeito significante sobre a altura depois de 2 a 3 anos de idade.

Através da seleção fenotípica no viveiro de mu das de pinus elliottii, SHIMIZU (1984) verificou continuidade de superioridade em altura, diâmetro e volume 5,5 anos após o plantio. Cita ainda que a seleção no viveiro permitiu ganho de $8,7 \%$ em altura, 17,5\% em DAP e 49,9\% em volume.

Em experimentos conduzidos no Estado de Oklahoma (EUA), com mudas de Pinus spp., STOECKELER (1967) concluiu que mudas de menor altura, mas com diâmetros maiores, apresentaram o melhor índice de pegamento após o plantio.

CARNEIRO (1976) em estudo feito com Pinus taeda L., com mudas de 8 a 11 meses de idade, observou após 15 meses de campo que a altura, nos três nỉveis de seleção fei- 
tos por ele, não apresentou significância estatística. Consi dera essa característica um fator desnecessārio para o emprego na classificação de qualidade de mudas, julgando que o diâa metro do colo é um parâmetro muito mais poderoso.

Algumas técnicas de manejo de mudas de Eucalyp tus, em viveiro, vêm sendo usadas por algumas empresas florestais, como: poda radicular e/ou poda do ápice da parte aérea; controle da fertilização e da irrigação, sem contudo, avaliar seus efeitos sobre o crescimento da floresta (REZENDE, 1978; CAF, 1980).

Sendo assim, REZENDE et alii (1984) trabalhando em regiões de cerrados com Eucalyptus grandis, testaram poda do ápice da parte aérea de $10 \mathrm{~cm}$ do ponteiro e do sistema radicular com $1,5 \mathrm{~cm}$ do fundo dó saco plástico, em mudas "verdes" (90 dias) e mudas maduras (165 dias). Apōs 12, 36 e 60 meses, não verificaram diferenças estatísticas em sobrevivência, DAP, altura e volume cilindrico.

SANCHES et alii (1989) estudando o comportamen to de Eucalyptus grandis e Eucalyptus urophylla, no Estado de São Paulo, verificaram que o $E$. grandis é a espécie de melhor produtividade, porém mais sujeita à mortalidade devido à seca edāfica. O E. urophylla apresentou um comportamento favorável com relação à resistência a seca.

STAPE et alii (1989) comparando o desenvolvimento de Eucalyptus grandis e Eucalyptus urophylla de diver- 
sas procedências e niveis de melhoramento em Areia Quartzosa, no Estado de São Paulo, observaram que o $E$. grandis procedente de Boa Esperança do Sul-SP/Pomar de Semente de Muda, alcan çou maior produtividade. Entre os E. urophylla, o procedente da região de Timor-Indonésia/Ârea de Produção de Sementes, foi o que obteve a melhor produtividade.

\subsection{CRescimento de ralzes}

As características de crescimento radicular de árvores são fortemente influenciadas pela espécie, competição, pelas raízes médias e pelas práticas culturais e, que por sua vez, a taxa e a duração do crescimento radicular varia sazonalmente e diuturnamente, de acordo com a espécie, idade da ārvore e o ambiente radicular (KOZLOWSKI, 1971).

PRITCHTT (1.979) cita que o crescimento e a distribuição de raízes são influenciados também por fatores ambientais que afetam o crescimento da árvore que fatores co mo textura do solo, compactação, umidade disponível, camadas de impedimento e nutrição podem influenciar a produção, a pro fundidade e a extensão do desenvolvimento radicular.

o mesmo autor cita, ainda, que provavelmente, a umidade tem maior influência sobre o desenvolvimento e a distribuição radicular do que alguns outros fatores do solo. Freqüentemente, taxa de crescimento lento de árvores, associa 
da com solos rasos, não è devido principalmente à falta de espaço para o desenvolvimento radicular, mas antes à limitação do fornecimento de água e nutrientes associado com enraizamento raso.

A temperatura do solo afeta em muitos aspectos - crescimentoe a distribuição radicular. LYR \& HOFFMAN (1967) citam que o mínimo, ótimo e máximo de temperatura do solo, pa ra o melhor crescimento da árvore, varia com a espécie e as condições ambientais. O mínimo para o crescimento radicular é ligeiramente acima de $0^{\circ}-7{ }^{\circ} \mathrm{C}$; o ótimo é de $10^{\circ}-30^{\circ} \mathrm{C} ;$ o máxi mo é de $25^{\circ}-30^{\circ} \mathrm{C}$.

As raízes podem não experimentar uma verdadeira dormência, mas um tipo de quietude pode ser induzida por fatores ambientais (ZIMMERMANN \& BROWN, 1971). Raizes de muitas espécies de clima quente e de crescimento rápido, como $P_{\underline{i}}$ nus radiata e muitos outros Eucalyptus, aparentemente nunca cessam completamente o crescimento durante os meses de inverno, embora sua taxa de crescimento possa ser diminuída pelo decréscimo da temperatura do solo (PRICHETT, 1979). Este autor cita que a acidez do solo e deficiência de nutrientes, ou mesmo o desbalanço nutricional, são condições químicas do solo mais determinantes para restringir o crescimento e desenvolvimento radicular em regiões úmidas.

KREJCI et alii (1986) observaram que os eucaliptos possuem sistemas radiculares diferenciados. Aos oito 
meses de idade em diferentes tipos e métodos de preparo do so 1o, o sistema radicular do Eucalyptus urophylla desenvolveuse preferencialmente nos primeiros $30 \mathrm{~cm}$ do solo. Com a retração da pivotante nas camadas adensadas, o sistema lateral emitiu raizes de "compensação", ou seja, uma outra raiz pivotante que pode tornar-se necessária como elemento auxiliar no suprimento hídrico em período de déficit. o Eucalyptus grandis apresentou raízes superficiais, com maior desenvolvimento no sentido horizontal e foi considerado sensivel às condições adversas.

ARNOTT (1978) em estudo de raízes de árvores plantadas, encontrou que os diferentes desenhos de recipientes modificaram subseqüentemente o desenvolvimento radicular no campo em diferentes caminhos, embora sinais dessas diferenças desapareçam com o crescimento da árvore.

EIS (1978) estudando a morfologia de raízes de coniferas de regeneração natural, cita que sistemas radiculares de árvores dominantes apresentam melhor desenvolvimento, com mais ramificações, melhor sistema e menor mortalidade de raízes, quando comparado com árvores de copa mais baixa. Em árvores suprimidas, observou 'que as raỉzes desenvolveram-se em apenas uma ou duas direções. 


\section{MATERIAL E PBÉTODOS}

\subsection{Espécies e OBTENGÃo DE SEMENTES}

As espécies de Eucalyptus utilizadas no presen te trabalho foram Eucalyptus grandis Hill ex Maiden e Eucalyp tus urophylla S.T. Blake.

As sementes utilizadas foram provenientes de polinização livre, para as duas espēcies. As sementes de Eucalyptus grandis foram procedentes de Botucatu-SP, que por sua vez são originárias de um pomar clonal de Sementes de Coff's Harbour-NSW-Austrália. As sementes de Eucalyptus urophylla foram procedentes de Avaré-SP, originārias de uma Ārea de Produção de Sementes de Bessi-Lao-Timor/Indonésia.

\subsection{RECIPIENTES}

\subsubsection{Tubetes de polietileno ("dibble tube ${ }^{m}$ )}

STAPE \& BALLONI (1987) descrevemos tubetes que foram utilizados para produção das mudas, como: tubos cônicos 
de fundo aberto, com capacidade de $50 \mathrm{~cm}^{3}$ e com quatro estrias internas salientes longitudinais e eqüidistantes. Esses tubetes foram colocados em mesas de telas galvanizadas, portanto, suspensos.

\subsubsection{Saco-plástico}

Os sacos plásticos que foram utilizados na for mação das mudas apresentaram as seguintes características: cor preta e dimensões aproximadas de $5,5 \mathrm{~cm}$ de diâmetro por $12,0 \mathrm{~cm}$ de altura, com perfuração lateral no terço inferior pa ra facilitar a drenagem do excesso de água.

\subsection{SUBSTRATOS UTILIZADOS}

Os substratos utilizados na formação de mudas para a obtenção dos tratamentos foram: composto orgânico (cas ca de eucalipto), vermiculita e mistura de ambos com as suas devidas proporções usados no tubete e terra de sub-solo usada no saco plástico.

o composto orgânico é produzido a partir de casca.de eucalipto retirada com a utilização do descascador industrial. Nó início da operação essa casca é parcialmente decomposta, apresentando coloração escura, e uniformizada atra 
vés de peneiramento (peneira 1 por $1 \mathrm{~cm}$ de malha) para retira da das partes mais grosseiras.

A esse material são adicionados de 5 a $10 \%$ (em volume) de cinza de caldeira, elevando o pH para faixas mais favoráveis à decomposição, bem como sulfato de amônio em quan tidade suficiente para baixar a relação $\mathrm{C} / \mathrm{N}$ para cerca de 25/ 1, o que representa aproximadamente $8 \mathrm{~kg}$ de sulfato de amônio por metro cúbico de casca.

Fez-se então as pilhas que foram umedecidas e cobertas com lona plástica. Periodicamente se fez revolvimen to para promover melhor aeração. A estabilização da temperatura interna da pilha permitiu detectar o final do processo que girou em torno de 60 a 100 dias, conforme STAPE \& BALLONI (1987) (Tabela 1).

o composto foi colocado num misturador (betoñeira) onde recebeu a adubação de acordo com a rabela 2.

A semeadura foi realizada, empregando-se o método direto com auxílio de um semeador. 
Tabela 1. Características físicas e químicas do composto orgâa co.

\begin{tabular}{|c|c|}
\hline Caracteristicas & Teor (\%) \\
\hline Umidade total (natural) a $100-110^{\circ} \mathrm{C}$ & 32,91 \\
\hline Matéria orgânica total (combustão) & 38,25 \\
\hline Carbono total (orgânico e mineral) & 21,25 \\
\hline Resíduo mineral total & 28,84 \\
\hline Carbono orgânico & 17,62 \\
\hline Matéria orgânica compostável & 31,72 \\
\hline Matéria orgânica resistente & 6,53 \\
\hline Nitrogênio total & 0,64 \\
\hline Fósforo $\left(\mathrm{P}_{2} \mathrm{O}_{5}\right)$ total & 0,03 \\
\hline Potāssio $\left(\mathrm{K}_{2} \mathrm{O}\right)$ total & 0,11 \\
\hline Cálcio (ca) total & 1,74 \\
\hline Magnésio (Mg) total & 0,04 \\
\hline Enxofre (S) total & 0,70 \\
\hline Relação $\mathrm{C} / \mathrm{N}$ (C total e $\mathrm{N}$ total) & $3 \cdot 3 / 1$ \\
\hline Relação C/N (C orgânico e $N$ total). & $28 / 1$ \\
\hline Indice de $\mathrm{pH}$ em $\mathrm{CaCl}_{2}, 0,01 \mathrm{~N}$ & 4,6 \\
\hline
\end{tabular}

Fonte: STAPE \& BALLONI (1987).

Tabela 2. Quantidade de fertilizantes utilizados por $1 \mathrm{~m}^{3}$ de composto.

\begin{tabular}{lr}
\hline Adubo & Quantidade \\
\hline NPK $(7: 21: 7) *+0,3 \%$ Zn $+0,5 \% \mathrm{~B}$ & $8,2 \mathrm{l}$ \\
Sulfato de magnésio & $400,0 \mathrm{~g}$ \\
Sulfato de ferro & $200,0 \mathrm{~g}$ \\
Sulfațo de manganês & $100,0 \mathrm{~g}$ \\
Sulfato de cobre & $50,0 \mathrm{~g}$ \\
\hline
\end{tabular}

* formulação líquida

Fonte: STAPE \& BALLONI (1987) 
A vermiculita é um mineral micáceo, com lâminas microscópicas que abrem ou esfoliam pelo aquecimento. A estrutura da vermiculita é basicamente aquela do talco, visto que contém uma camada coordenada octaedricamente central de íns que permanecem entre duas lâminas de tetraedros de silício. Existem dois tipos principais de ocorrência de vermí culita, uma como produto de alteração pelo intemperismo ou ação hidrotermal da biotita; outra forma de ocorrência é na região de contato entre rochas intrínsecas, ácidas e básicas ou ultrabāsicas, tais como piroxenitas, peridotitas, dermitas etc. (DEER et alii, 1971).

A vermiculita após o processo de industrializa ção, se torna um material leve, puro, esterilizado, incombustí vel, insolúvel em água e solventes orgânicos, não sendo tóxica, abrasiva e nem deteriorável. Apresenta ainda, alta capacidade de troca catiônica e de absorção de um grande volume de água e outros líquidos. Possui micro estruturas com carac teristicas físico-quimicas especiais que the confere boas qua lidades. granulometria fina.

A vermiculita utilizada como substrato foi de

- Propriedades químicas médias da vermiculita:

$$
\begin{aligned}
& \mathrm{MgO}(\%)-24,20 \\
& \mathrm{CaO}(\%)-7,33 \\
& \mathrm{SiO}(\%) \\
& \mathrm{Fe}_{2} \mathrm{O}_{3}(\%)-43,27 \\
& \mathrm{TiO}_{2}(\%)-4,25 \\
&
\end{aligned}
$$




$$
\begin{aligned}
& \mathrm{Na}_{2} \mathrm{O}(\%)-1,27 \\
& \mathrm{~K}_{2} \mathrm{O}(\%)-1,27 \\
& \mathrm{~K}_{2} \mathrm{O}(\%)-\text { solúvel em água }-0,03 \\
& \mathrm{P}_{2} \mathrm{O}_{5}(\%)-0,08 \\
& \mathrm{AI}_{2} \mathrm{O}_{3}(\%)-9,58 \\
& \text { Perda ao fogo (\%) - } 8,22 \\
& \mathrm{CTC}(\text { eq. mg/100 g de solo)- } 95,00 \\
& \text { Poder de neutralização (\% } \left.\mathrm{CaCO}_{3}\right)-47,00 \\
& \mathrm{pH}-8,1
\end{aligned}
$$

Para o enchimento dos sacos plásticos utilizou-se um substrato areno-argiloso, proveniente do subsolo de un Latossolo Vermelho-Amarelo.

\subsection{LOCAL DO EXPERIMENTO}

o experimento foi realizado em uma área do Par que Florestal Flexa Azul, pertencente à Ripasa S/A Papel e Ce lulose, localizada no município de Boa Esperança do Sul, Esta

do de são Paulo, na latitude de $21^{\circ} 57^{\prime} \mathrm{s}$, longitude $48^{\circ} 32^{\prime} \mathrm{W}$, a uma altitude de 550 metros. As mudas foram produzidas no viveiro do próprio Parque Florestal.

\subsubsection{Clima e solo}

o clima da região é tropical de inverno seco, com precipitação média anual de $1.339 \mathrm{~mm}$, a temperatura média do mês mais quente e o mês mais frio são de $25,75^{\circ} \mathrm{C}$ e $18^{\circ} \mathrm{C}$, respectivamente (Tabela 3 e Figura 1 ). 


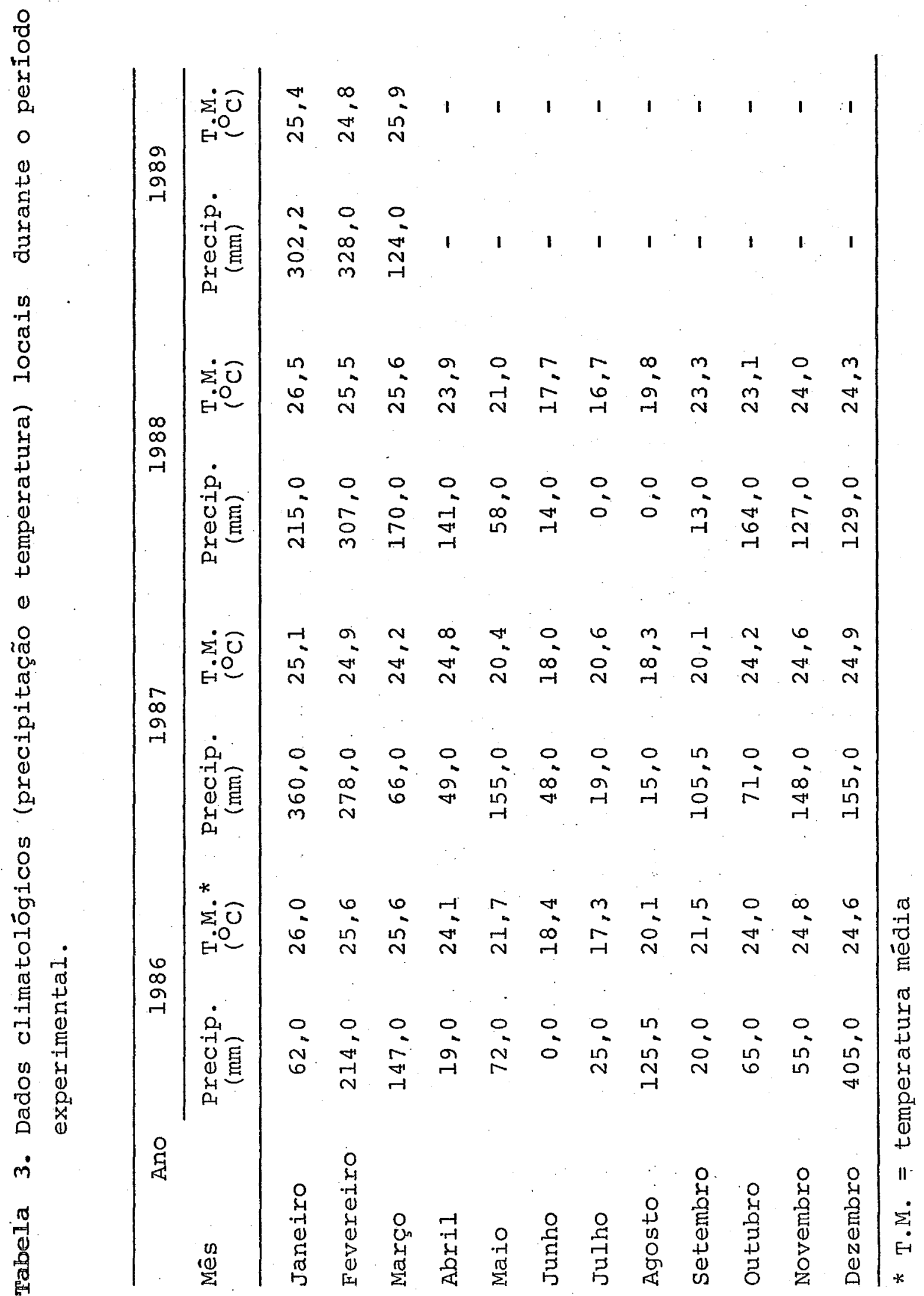




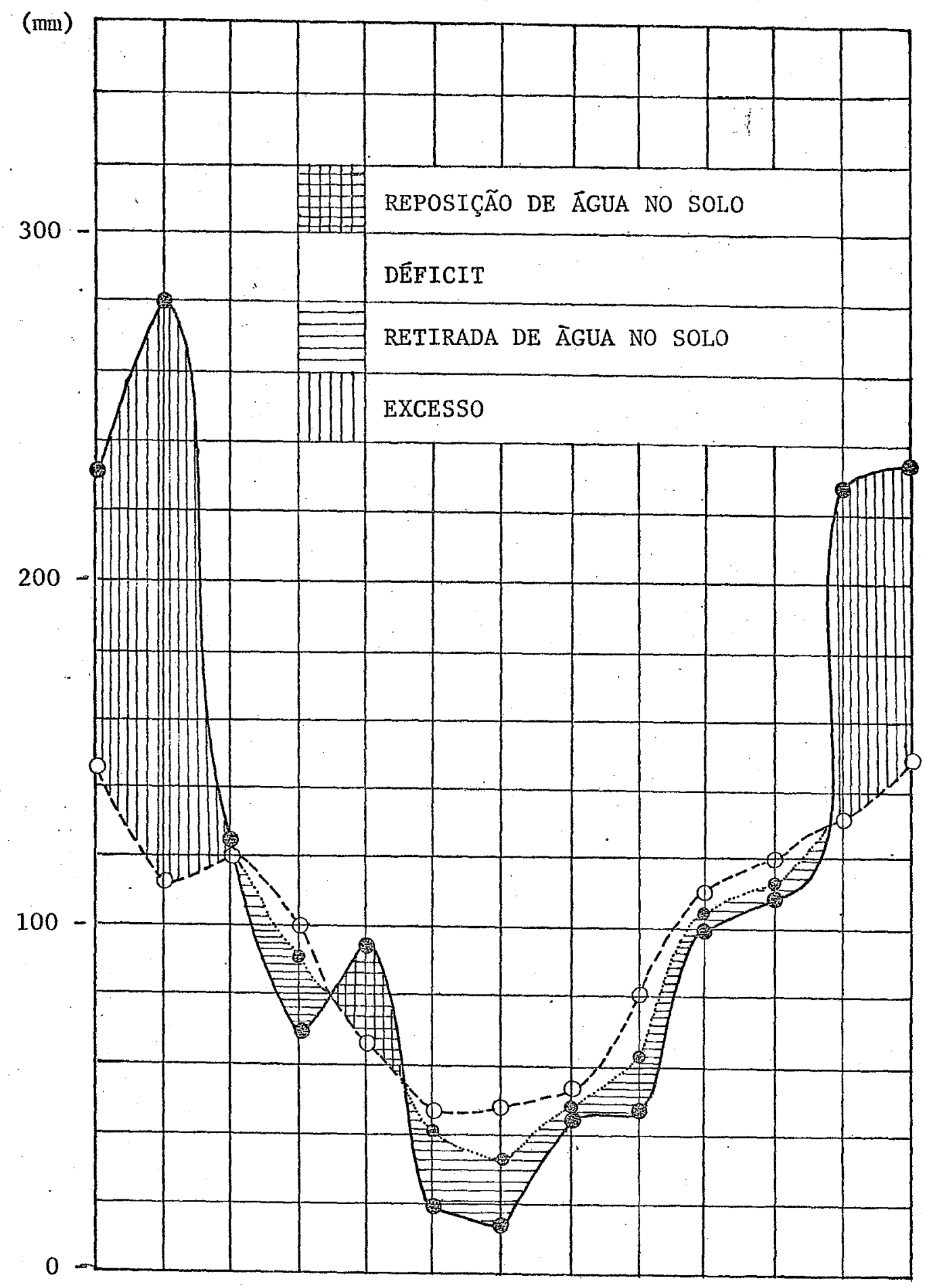

Jan Fev Mar Abr Mai Jun Jul Ago Set Out Nov Dez (meses).

Figura 1. Balanço hídrico mensal, segundo THORNTHWHITE \& MATHER (1955), para a Fazenda Flexa Azul, em Boa Espe rança do Sul-SP, baseado em dados termo-pluviométricos do período de 1986 - março/1989. 
A área experimental è bastante homogênea em suas características físicas e químicas. Apresenta um solo classificado como Areia Quartzosa, relevo suavemente ondulado,

- originalmente sob vegetação de cerrado. o resultado da análí se do solo da ārea experimental está apresentado na Ilabela 4.

\subsection{DELINEAMENTO EXPER IMEEMTAL}

o esquema estatístico adotado foi o fatorial em blocos ao acaso com 12 tratamentos e 3 repetições. Cada tratamento foi formado pelas referidas espécies, o tipo e a proporção do substrato, tipo de recipiente e altura média das mudas, conforme o a Tabela 5 .

As parcelas foram constituídas de 100 plantas ( $10 \times 10)$, no espaçamento de $3 \times 2 \mathrm{~m}=6 \mathrm{~m}^{2}$, ocupando uma área de $600 \mathrm{~m}^{2}$. Foram consideradas plantas üteis as 36 centrais $(6 \times 6)$ que ocuparam uma área de $216 \mathrm{~m}^{2}$, e as demais constituíram a borda dura. A área total do experimento foi de $21.600 \mathrm{~m}^{2}$, com um total de 36 parcelas e 3.600 plantas.

- Esquema da análise de variância

\begin{tabular}{lc}
\hline Causas de Variação & G.L. \\
\hline Blocos & $02:$ \\
Tratamentos & 11 \\
Resíduos & 22 \\
Espécie (E) & 01 \\
Substrato (S) & 05 \\
Intexação (E X S) & 05 \\
\hline Total & 35 \\
\hline
\end{tabular}




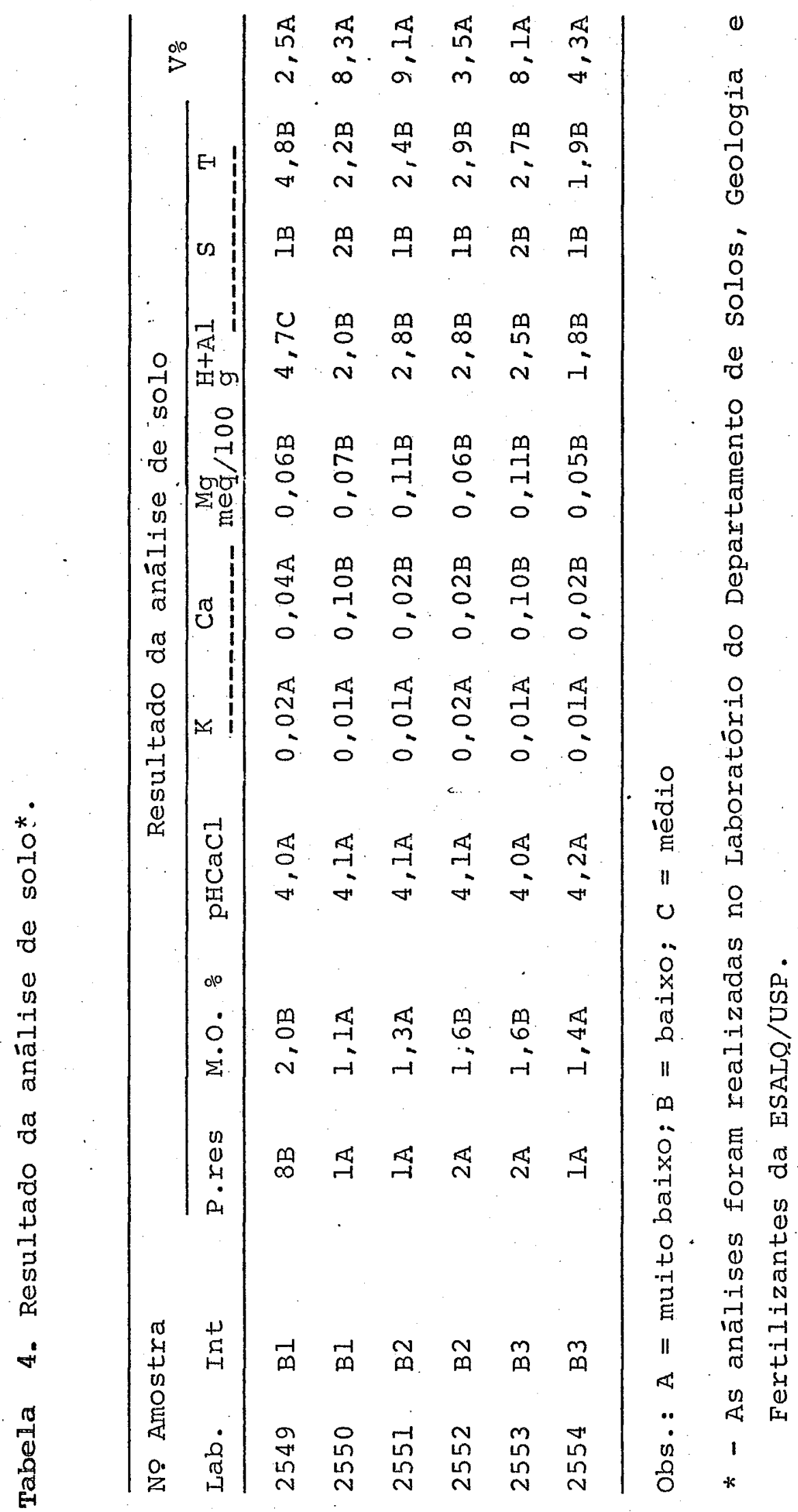




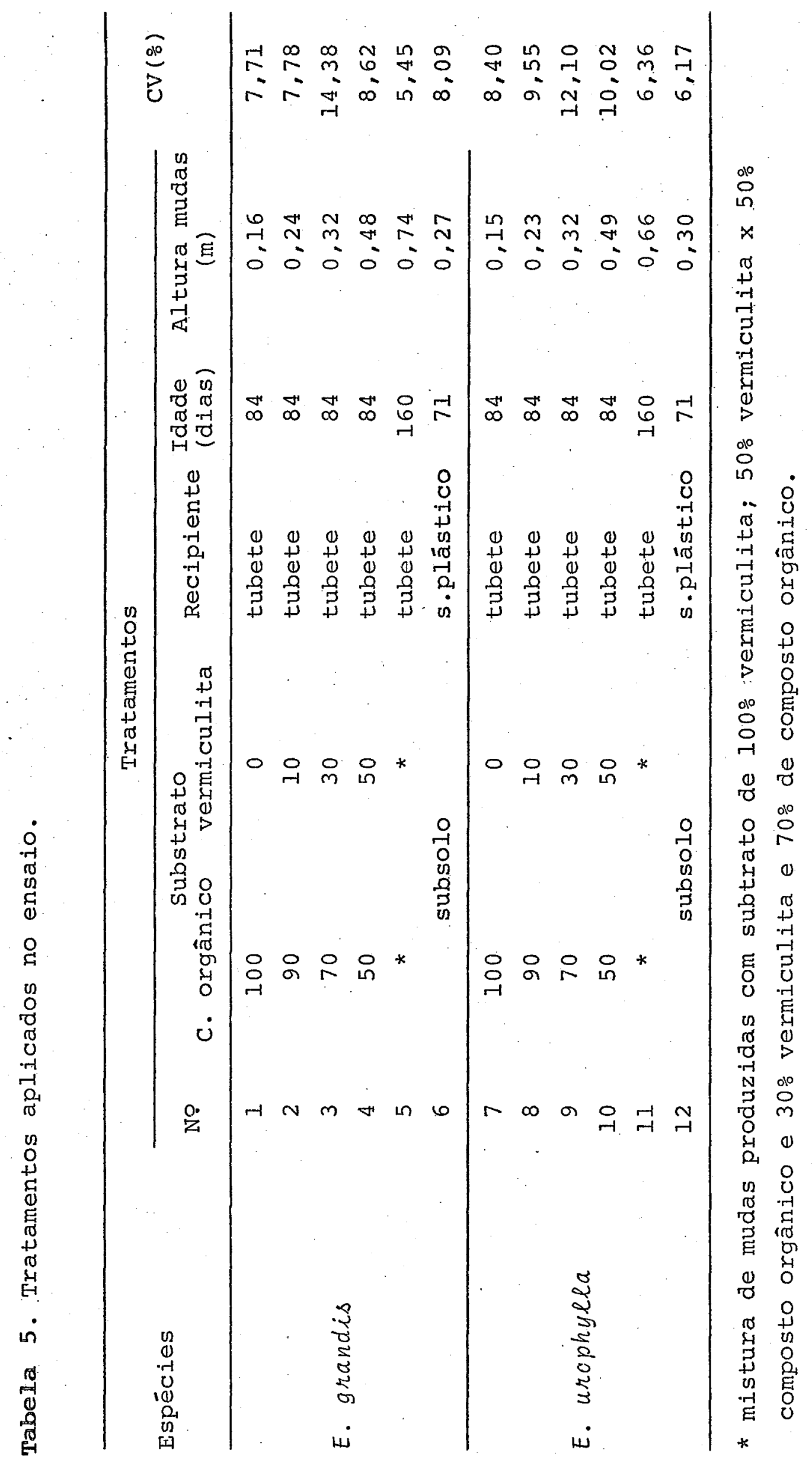




\subsection{InSTALAgão DO EXPERIMENTO}

\subsubsection{Preparo do solo e adubação}

o preparo do solo em área de reforma consti tuiu-se de revolvimento feito pelo arado reformador, cujo objetivo foi cobrir com uma camada de $25-30 \mathrm{~cm}$ de terra as tou ças, cortadas na superfície do solo, a fim de inibir a brotação, evitando-se o uso de produtos químicos (PRADO, 1989).

A adubação foi realizada em duas etapas: 4 dias antes do plantio aplicaram-se $120 \mathrm{~g}$ de NPK da fórmula 06:30:06 por planta no sulco de plantio e aproximadamente 90 dias após o plantio,50 $\mathrm{g}$ de NPK da fórmula 12:06:12 + 10 $\mathrm{g}$ de micro-nutriente por planta da fórmula FTE BR 9 (B, $\mathrm{Zn}, \mathrm{Cu}$, Mn e Fe).

\subsubsection{Plantio e tratos culturais}

o plantio foi feito pelo método manual, em fevereiro de 1986.

Os tratos culturais realizados foram os normais à cultura do eucalipto, incluindo controle de formigas, capina manual nas linhas e passagem de grade leve nas entre linhas durante o primeiro ano, até completa ocupação do terre no pelas árvores. 


\subsection{AVALIAGÃo DO EXPERIMENTO}

o experimento foi avaliado no campo, nas idades de 6 e 13 meses, coletando-se dados de altura total, fa1has, plantas mortas e vivas. Aos 37 meses de idade, acrescentou-se às características mencionadas, O DAP (diâmetro à altura do peito), ārea basal, volume cilíndrico e bifurcação.

As medições de altura e DAP foram feitais segundo os esquemas usuais, utilizando-se o hipsômetro "Blume Leiss" e a fita métrica, respectivamente, somente nas plantas úteis de cada parcela, de onde foram obtidas as médias dos tratamentos.

As características de sobrevivência de plantas e bifurcação foram obtidas pela contagem de plantas em cada parcela e expressas em termos percentuais em relação ao número total de plantas que deveria conter a parcela. Para efeito de análises, fez-se a transformação dos dados de percentagem para arc sen $\sqrt{x / 100}$, conforme recomenda GOMES (1987)。

A análise estatística foi feita através do tes te $F$, com e sem o desdobramento dos graus de liberdade; e do teste de Tukey, para comparação entre médias dos tratamentos. Para isso utilizou-se o programa SAS. 


\subsection{Morfologia das raizes}

Para efeito de observação da morfologia ... das raizes, foram realizadas escavações manuais em volta do siste ma radicular, formando-se trincheiras de aproximadamente $1 ; 0 \mathrm{~m}$ de raio em relação à base do fuste e 0,80 a $1,0 \mathrm{~m}$ de profundi dade.

os resultados são baseados em uma amostra de 16 árvores, sendo cada uma selecionada em função da espécie, do tipo de recipiente utilizado na produção das mudas e dos estratos da altura das árvores no povoamento, ou seja, dominante, dominada, média e também ārvores mortas. Após a completa abertura das trincheiras, foram efetuadas algumas observações da morfologia no campo e complementado através de fotografias do sistema radicular.

A Tabela 6 apresenta os dados de altura e DAP das ārvores selecionadas para descrição das raízes, em função do tipo de recipiente utilizado na produção de mudas e " dos estratos da altura das árvores no povoamento, por espécie, aos 39 meses de idade. 
Tabela 6. Altura e DAP das árvores selecionadas em função do recipiente e dos estratos de altura das árvores, aos 39 meses de idade.

\begin{tabular}{|c|c|c|c|c|c|c|c|c|}
\hline \multirow{3}{*}{$\begin{array}{l}\text { Tratamento } \\
\text { Estrato }\end{array}$} & \multicolumn{4}{|c|}{ E. grandis } & \multicolumn{4}{|c|}{ E. urophylla } \\
\hline & \multicolumn{2}{|c|}{ saco plāstico } & \multicolumn{2}{|c|}{ tubete } & \multicolumn{2}{|c|}{ saco plāstico } & \multicolumn{2}{|c|}{ tubete } \\
\hline & $\begin{array}{l}\text { altura } \\
\text { (m) }\end{array}$ & $\begin{array}{l}\mathrm{DAP} \\
(\mathrm{cm})\end{array}$ & $\underset{(\mathrm{m})}{\text { altura }}$ & $\begin{array}{l}\text { DAP } \\
(\mathrm{cm})\end{array}$ & $\begin{array}{c}\text { altura } \\
\text { (m) }\end{array}$ & $\begin{array}{l}\text { DAP } \\
(\mathrm{cm})\end{array}$ & $\begin{array}{c}\text { altura } \\
\text { (m) }\end{array}$ & $\begin{array}{c}\text { DAP } \\
(\mathrm{cm})\end{array}$ \\
\hline Dominante & 18,00 & 13,85 & 19,10 & 14,33 & 17,50 & 14,30 & $18 ; 10$ & 15,10 \\
\hline Média & 16,00 & 10,00 & 16,90 & 11,30 & 14,40 & 8,90 & 14,30 & 10,20 \\
\hline Dominada & 11,80 & 7,00 & 12,30 & 6,70 & 9,00 & 6,50 & 10,40 & 5,10 \\
\hline Morta & 15,30 & 10,80 & 15,20 & 11,46 & 10,80 & 6,40 & 10,00 & 5,40 \\
\hline
\end{tabular}

Os dados de altura e DAP das espécies, em função do estrato que ocupam no povoamento, mostraram um cresci-. mento bem diferenciado das árvores para descrição de suas raízes, pois tratam-se de dados individuais por árvores, sele cionadas ao acaso, em função dos tratamentos estabelecidos. 


\section{RESULTADOS E DISCUSSÃ0}

\subsection{Comportamento das plantas no CAMPo}

\subsubsection{Avaliação aos 6 meses de idade}

Os dados de altura e sobrevivência : (falhas, plantas mortas e vivas) para as duas espécies submetidas aos diferentes tratamentos são apresentados na Tabela 7 .

Tabela 7. Crescimento em altura e sobrevivência (falhas, plan tas mortas e vivas) nos diferentes tratamentos, aos 6 meses de idade.

\begin{tabular}{|c|c|c|c|c|c|}
\hline \multirow[b]{2}{*}{ Espécies } & \multirow{2}{*}{$\begin{array}{c}\text { Tratamento } \\
\text { No }\end{array}$} & \multirow{2}{*}{$\begin{array}{l}\text { Altura } \\
\text { (m) }\end{array}$} & \multicolumn{3}{|c|}{ Sobrevivência } \\
\hline & & & $\begin{array}{c}\text { Falha } \\
(\%)\end{array}$ & $\begin{array}{l}\text { Plantas } \\
\text { mortas } \\
(\%)\end{array}$ & $\begin{array}{c}\text { Plantas } \\
\text { vivas } \\
\text { (\%) }\end{array}$ \\
\hline E. grandis. & $\begin{array}{l}1 \\
2 \\
3 \\
4 \\
5 \\
6\end{array}$ & $\begin{array}{l}2,47 \\
2,43 \\
2,43 \\
2,50 \\
2,48 \\
2,55\end{array}$ & $\begin{array}{l}0,00 \\
0,93 \\
1,86 \\
2,78 \\
0,93 \\
1,86\end{array}$ & $\begin{array}{l}0,00 \\
0,93 \\
0,00 \\
0,93 \\
0,00 \\
0,00\end{array}$ & $\begin{array}{r}100,00 \\
98,14 \\
98,14 \\
96,29 \\
99,07 \\
98,14\end{array}$ \\
\hline Média & & 2,48 & 1,39 & 0,31 & 98,30 \\
\hline E. urophylla & $\begin{array}{r}7 \\
8 \\
9 \\
10 \\
11 \\
12\end{array}$ & $\begin{array}{l}2,04 \\
1,93 \\
1,88 \\
2,09 \\
1,99 \\
2,08\end{array}$ & $\begin{array}{l}0,00 \\
1,86 \\
1,86 \\
0,93 \\
0 \\
0,93\end{array}$ & $\begin{array}{l}0,00 \\
0,93 \\
0,00 \\
0,93 \\
0,93 \\
0,00\end{array}$ & $\begin{array}{r}100,00 \\
97,21 \\
98,14 \\
98,14 \\
99,07 \\
99,07\end{array}$ \\
\hline Mëdia & & 2,00 & 0,93 & 0,46 & 98,60 \\
\hline
\end{tabular}


A Tabela 8 apresenta os resultados da análise de variância das variáveis altura das plantas e sobrevivência (falhas, plantas mortas e vivas) das espécies de Eucalyptus grandis e Eucalyptus urophylla, aos 6 meses de idade.

Tabela 8. Análises de variância de altura e de sobrevivência, com dados percentuais transformados em arc sen $\sqrt{\mathrm{x} / 10,0}$ aos 6 meses de idade.

\begin{tabular}{|c|c|c|c|c|c|}
\hline \multirow{2}{*}{ Espécie } & \multirow{2}{*}{$\begin{array}{l}\text { Ordem dos } \\
\text { tratamentos. }\end{array}$} & \multirow{2}{*}{$\begin{array}{l}\text { Altura } \\
\text { (m) }\end{array}$} & \multicolumn{3}{|c|}{ Sobrevivência } \\
\hline & & & Falhas & $\begin{array}{r}\text { Plantas } \\
\text { mortas }\end{array}$ & $\begin{array}{l}\text { Plantas } \\
\text { vivas }\end{array}$ \\
\hline E. grandis & $\begin{array}{l}6 \\
4 \\
5 \\
1 \\
2 \\
3\end{array}$ & $\begin{array}{l}2,55 a \\
2,50 a \\
2,48 a \\
2,47 a \\
2,43 a b \\
2,43 a b\end{array}$ & $\begin{array}{l}0,13 \\
0,18 \\
0,13 \\
0,10 \\
0,13 \\
0,16\end{array}$ & $\begin{array}{l}0,10 \\
0,13 \\
0,10 \\
0,10 \\
0,13 \\
0,10 .\end{array}$ & $\begin{array}{l}1,57 \\
1,52 \\
1,57 \\
1,57 \\
1,52 \\
1,57\end{array}$ \\
\hline E. urophyle & $\begin{array}{r}10 \\
12 \\
7 \\
11 \\
8 \\
9\end{array}$ & $\begin{array}{l}2,09 \mathrm{cb} \\
2,08 \mathrm{cb} \\
2,04 \mathrm{c} \\
1,99 \mathrm{c} \\
1,93 \mathrm{c} \\
1,88 \mathrm{c}\end{array}$ & $\begin{array}{l}0,13 \\
0,13 . \\
0,10 \\
0,10 \\
0,16 \\
0,15 .\end{array}$ & $\begin{array}{l}0,13 \\
0,10 \\
0,10 \\
0,13 \\
0,13 . \\
0,10\end{array}$ & $\begin{array}{l}1,52 \\
1,57 \\
1,57 \\
1,52 \\
1,52 \\
1,57\end{array}$ \\
\hline Mēdia & - & 2,24 & 0,13 & 0,11 & 1,55 \\
\hline Teste F & & $12,97 * *$ & $0,85^{\mathrm{ns}}$ & $0,66^{\mathrm{ns}}$ & $0,66^{\mathrm{ns}}$ \\
\hline DMS & & 0,36 . & 0,15 & $0,10$. & 0,14 \\
\hline $\mathrm{CV}\left(\frac{\%}{0}\right)$ & & 5,50 & 37,82 & 30,80 & 3,15 \\
\hline
\end{tabular}

OBS.: As médias seguidas pela mesma letra não diferem estatisticamente ao nivel de $5 \%$ de probabilidade.

** = altamente significativo

ns = não significativo ao nível de 5\% de probabilidade 
As Figuras 2 e 3 ilustram, respectivamente, o - comportamento da altura dos eucaliptos nos diferentes tratamentos e a comparação do crescimento entre as espécies aos 6 meses de idade.

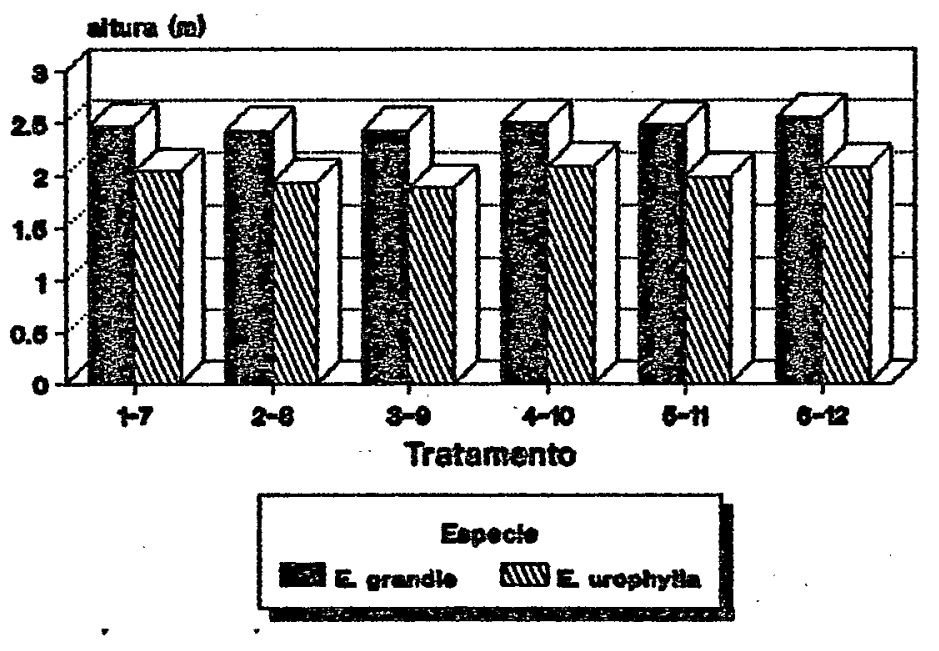

Figura 2. Altura média dos eucaliptos nos diferentes tratamen tos, aos 6 meses de idade.

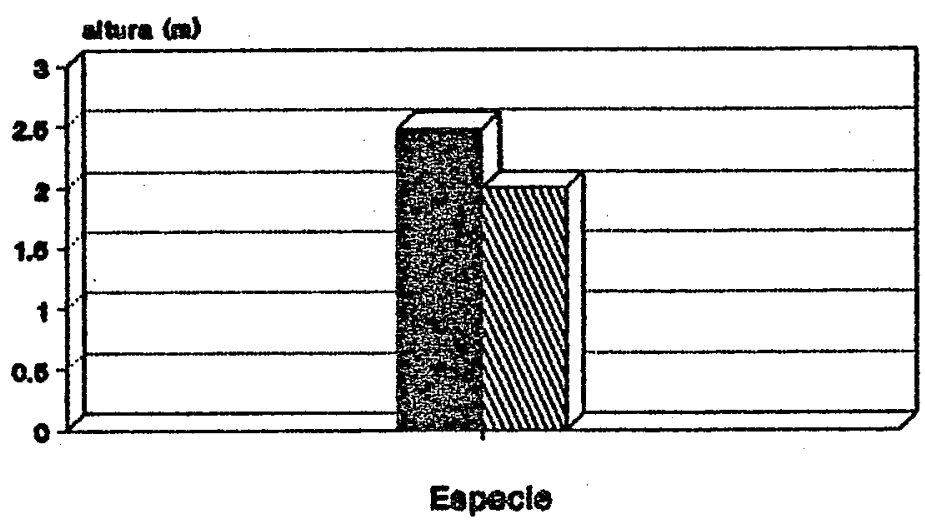

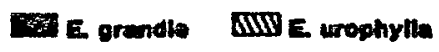

Figura 3. Altura média das espécies de eucaliptos, aos 6 meses de idade. 
Verifica-se pela Tabela 8 que o teste $F$ para a variāvel altura das árvores, revelou diferença altamente significativa entre os tratamentos. Na comparação das médias en tre os tratamentos, o teste de Tukey detectou equivalências estatísticas dentro de espēcie, evidenciando diferenças apenas entre as espécies, ao mesmo nível de probabilidade.

Com relação aos dados de sobrevivência, o teste $\mathrm{F}$ revelou que não houve diferença significativa entre os tratamentos, ao nível de 5\% de probabilidade.

A Tabela 9 apresenta os resultados do desdobra mento dos graus de liberdade da altura entre as espécies.

Tabela 9. Desdobramento dos graus de liberdade, para altura (m) entre espécie, aos 6 meses de idade.

Espëcie

Altura média (m)
E. grandis
$2,48 a$
E. urophylla
$2,00 \mathrm{~b}$
Teste F
$133,98 * *$
DMS (5\%)
0,08
OBS.: As médias seguidas pela mesma letra não diferem estatís ticamente, ao nível de 5\% de probabilidade.
** =. altamente significativo
CV (\%) para: E. grandis $=18,58 ;$. E. urophylla $=24,41$ 
Observa-se na Tabela 9 que o teste $F$ revelou efeito altamente significativo para espēcie, não mostrando significância para os tratamentos dentro de espécie e nem para interação espécie $\mathrm{x}$ tratamento, ao nível de 5\% de probabiIidade.

A análise da altura das mudas após o plantio, evidenciou o efeito da espécie no crescimento das plantas, onde pôde-se observar a recuperação do crescimento das mudas no campo, que eram menores em tamanho e idade por ocasião do plantio.

As diferenças em substratos e suas proporções, recipientes, idade e tamanho das mudas por ocasião do plantio, revelaram-se um indicador pobre do comportamento do cres cimento das plantas no campo, já aos 6 meses de idade, dentro da mesma espēcie.

observa-se que apesar de não se ter verificado diferenças estatísticas entre tratamentos, as maiores alturas médias encontradas por espécie foram no tratamento 6 (substrato: subsolo; recipiente: saco plástico; idade: 71 dias; altura de mudas: $0,27 \mathrm{~cm}$ ) para 0 Eucalyptus grandis e no tratamento 10 (substrato: 50\% comporto orgânico x 50\% vermiculita; recipiente: tubete; idade: 84 dias; altura das mudas: $0,49 \mathrm{~cm}$ ) para o Eucalyptus urophylla. 
- Eucalyptus grandis mostrou-se com maior cres cimento e maior uniformidade, apresentando um coeficiente de variação de 18,58\%, enquanto que o Eucalyptus urophylla apresentou uma altura de $2,00 \mathrm{~m}$ e um coeficiente de variação de $24,41 \%$.

BRIGATTI (1983) observou uma discreta tendência de aumento da altura de plantas de Eucalyptus grandis, em função do seu tamanho por ocasião do plantio, embora essas dị ferenças não tenham sido significativas.

COELHO (1984) tendo utilizado laminado de pinho como recipiente e um substrato areno-argiloso, verificou que a seleção por tamanho de muda, em Eucalyptus grandis, tem efeitos significativos sobre o crescimento em altura no campo.

Quanto ao efeito de recipientes e substratos no crescimento de mudas no campo, STAPE \& BALLONI (1987) encon traram em Eucalyptus grandis, que mudas produzidas em sacos plásticos e substrato areno-argiloso apresentaram melhor cres cimento e uniformidade, aos 6 meses de idade, quando comparadas com as mudas produzidas em tubete e proporções de casca composta e vermiculita. 
o eficiente resultado obtido na sobrevivência das plantas no campo para todos os tratamentos, pode ser atrí buído às condições favoráveis nas quais foi realizado o plantio. As mudas estavam com as idades e tamanhos adequados, o solo convenientemente preparado e as condições climáticas eram bastante favoráveis para a realização desta operação de plantio.

AGUIAR (1973) tambēm atribuiu às vantajosas condições de plantio a alta sobrevivência das mudas de Eucalyptus grandis e Eucalyptus saligna, produzidas em quatro diferentes recipientes, não constatando diferenças entre eles, no que diz respeito ao pegamento das mudas após o plantio no campo.

As diferenças na sobrevivência encontradas por alguns autores na literatura, podem ser resultantes de condições menos adequadas de plantio e desenvolvimento inicial das mudas.

\subsubsection{Avaliação aos 13 meses de idade}

Os dados de crescimento em altura e de sobrevivência são apresentados na Tabela 10 . 
Tabela 10. Crescimento em altura e sobrevivência (falhas, plantas mortas e vivas), nos diferentes tratamentos, aos 1.3 meses de idade.

\begin{tabular}{|c|c|c|c|c|c|}
\hline \multirow[b]{2}{*}{ Espécies } & \multirow{2}{*}{$\begin{array}{c}\text { Tratamento } \\
\text { no }\end{array}$} & \multirow{2}{*}{$\begin{array}{l}\text { Altura } \\
\text { (m) }\end{array}$} & \multicolumn{3}{|c|}{ Sobrevivência } \\
\hline & & & $\begin{array}{c}\text { Falha } \\
\text { (\%) }\end{array}$ & $\begin{array}{l}\text { Plantas } \\
\text { mortas } \\
\left(\frac{\circ}{0}\right)\end{array}$ & $\begin{array}{c}\text { Plantas } \\
\text { vivas } \\
\text { (\%) }\end{array}$ \\
\hline E. grandis & $\begin{array}{l}1 \\
2 \\
3 \\
4 \\
5 \\
6\end{array}$ & $\begin{array}{l}7,23 \\
7,22 \\
7,20 \\
7,44 \\
7,16 \\
7,29\end{array}$ & $\begin{array}{l}0,00 \\
0,93 \\
1,85 \\
2,78 \\
0,93 \\
1,85\end{array}$ & $\begin{array}{l}1,85 \\
2,78 \\
2,78 \\
0,93 \\
0,00 \\
0,00\end{array}$ & $\begin{array}{l}98,15 \\
96,29 \\
95,37 \\
96,29 \\
99,07 \\
98,15\end{array}$ \\
\hline Média: & - & 7,26 & 1,39 & 1,39 & 97,22 \\
\hline E. urophylla & $\begin{array}{r}7 \\
8 \\
9 \\
10 \\
11 \\
12\end{array}$ & $\begin{array}{l}6,05 \\
5,92 \\
5,63 \\
6,23 \\
5,80 \\
6,30\end{array}$ & $\begin{array}{l}0,00 \\
1,85 \\
1,85 \\
0,93 \\
0,00 \\
0,93\end{array}$ & $\begin{array}{l}0,00 \\
0,93 \\
0,00 \\
0,93 \\
0,93 \\
0 .\end{array}$ & $\begin{array}{r}100,00 \\
97,22 \\
98,15 \\
98,14 \\
99,07 \\
99,07\end{array}$ \\
\hline Média & - & 5,99 & 0,92 & 0,46 & 98,61 \\
\hline
\end{tabular}

As Figuras 4 e 5 ilustram, respectivamente, a altura média dos eucaliptos nos diferentes tratamentos e a altura média das espécies, aos 13 meses de idade. 


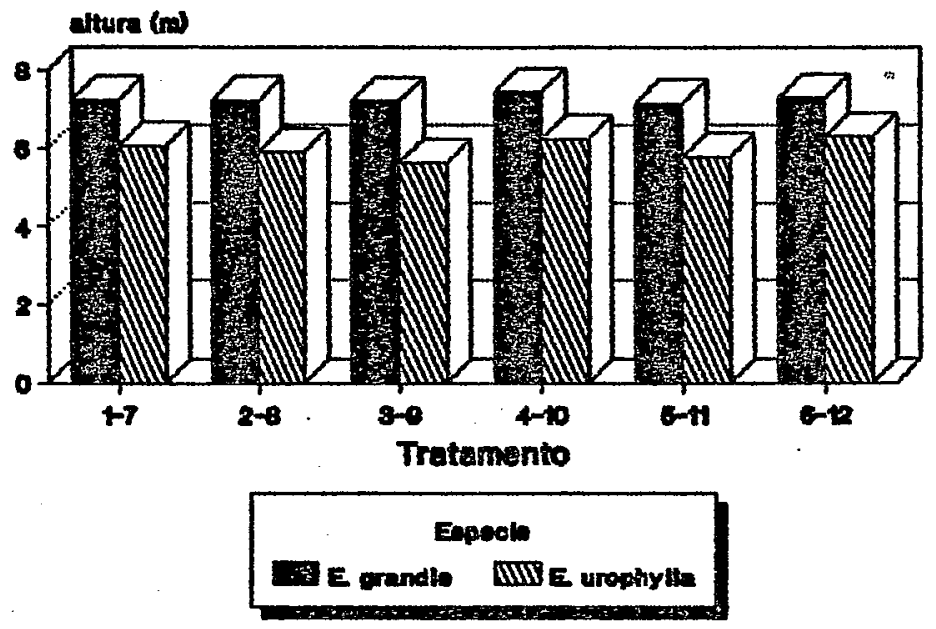

Figura 4. Altura média das espécies de elicaliptos nos diferen tratamentos, aos 13 meses de idade.

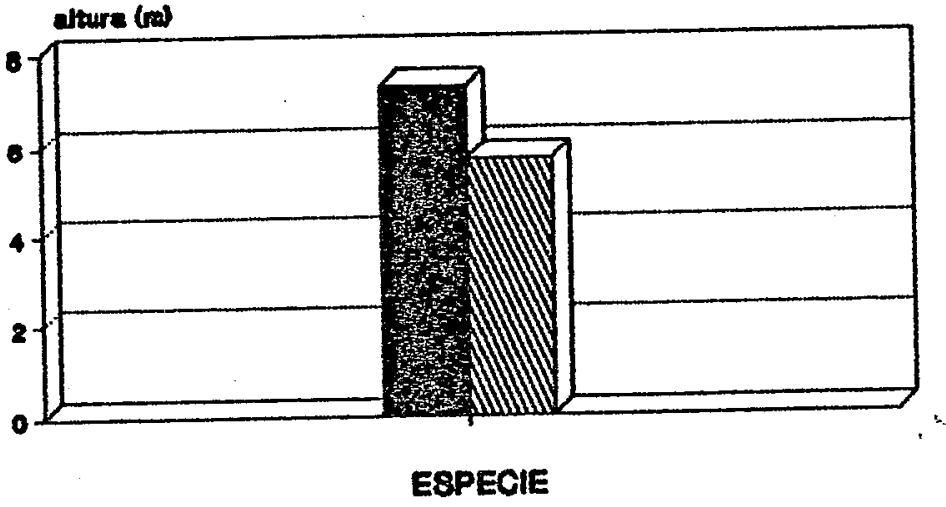

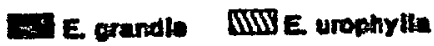

Figura 5. Altura mëdia das espēcies de eucaliptos, aos 13 meses de idade. 
Os dados de altura de plantas nos diferentes tratamentos, continuam evidenciando o crescimento mais expres sivo do Eucalyptus grandis, em comparação ao Eucalyptus urophylla, e na sobrevivềncia os resultados praticamente seguiram a mesma tendência verificada aos 6 meses de idade.

A Tabela 11 apresenta os resultados da análise de variância da altura das plantas e de sobrevivência, aos 13 meses de idade.

Nos resultados de crescimento em altura . das plantas, o valor de $F$ revelou diferenças altamente significativas entre tratamentos, ao nível de 5\% de probabilidade. Na comparação das médias entre tratamentos, o teste de Tukey detectou diferenças significativas no mesmo nível de probabilidade, porém com uma menor variação de altura entre os tratamentos, quando comparadas com a anālise aos 6 meses de idade.

Com relação aos dados de sobrevivência, o teste $F$ não detectou diferença estatística entre os tratamentos, ao inivel de 5\% de probabilidade. 
Tabela 11. Anālises de variância de altura e de sobrevivência, com dados percentuais transformados em arc sen $\sqrt{\mathrm{x} / 100}$, aos 13 meses de idade.

\begin{tabular}{|c|c|c|c|c|c|}
\hline \multirow{2}{*}{ Espécies } & \multirow{2}{*}{$\begin{array}{l}\text { Ordem dos } \\
\text { tratamentos }\end{array}$} & \multirow{2}{*}{$\begin{array}{c}\text { Altura } \\
\text { (m) }\end{array}$} & \multicolumn{3}{|c|}{ Sobrevivência } \\
\hline & & & Falhas & $\begin{array}{l}\text { Plantas } \\
\text { mortas }\end{array}$ & $\begin{array}{c}\text { Plantas } \\
\text { vivas }\end{array}$ \\
\hline E. grandis & $\begin{array}{l}4 \\
6 \\
1 \\
2 \\
3 \\
5\end{array}$ & $\begin{array}{l}7,44 \mathrm{a} \\
7,29 \mathrm{ab} \\
7,23 \mathrm{ab} \\
7,22 \mathrm{ab} \\
7,20 \mathrm{ab} \\
7,16 \mathrm{ab}\end{array}$ & $\begin{array}{l}0,18 \\
0,15 \\
0,10 \\
0,13 \\
0,16 \\
0,13\end{array}$ & $\begin{array}{l}0,13 \\
0,10 \\
0,16 \\
0,18 \\
0,18 \\
0,10\end{array}$ & $\begin{array}{r}1,52 \\
1,57 \\
1,48 \\
1,45 \\
1,45 \\
1,57\end{array}$ \\
\hline E. urophylla & $\begin{array}{r}7 \\
12 \\
10 \\
8 \\
11 \\
9\end{array}$ & $\begin{array}{l}6,38 \mathrm{abc} \\
6,30 \mathrm{bc} \\
6,23 \mathrm{bc} \\
5,92 \mathrm{c} \\
5,80 \mathrm{c} \\
5,63 \mathrm{c}\end{array}$ & $\begin{array}{l}0,10 \\
0,13 \\
0,13 \\
0,16 \\
0,10 \\
0,15\end{array}$ & $\begin{array}{l}0,10 \\
0,10 \\
0,13= \\
0,13 \\
0,13 \\
0,10\end{array}$ & $\begin{array}{r}1,57 \\
1,57 \\
1,52 \\
1,52 \\
\therefore \quad 1,52 \\
1,57\end{array}$ \\
\hline Média & - & 6,65 & 0,1373 & 0,1302 & 1,5291 \\
\hline Teste $F$ & & $9,81 * *$ & $0,75^{\mathrm{ns}}$ & $1,35^{\mathrm{ns}}$ & $1,34^{\mathrm{ns}}$ \\
\hline DMS (Tukey 5 & $5 \%)$ & 1,10 & 0,16 & 0,14 & 0,19 \\
\hline $\mathrm{CV}\left(\frac{\circ}{0}\right)$ & & 5,58 & 40,36 & 37,29 & 4,38 \\
\hline
\end{tabular}

OBS.: As médias seguidas pela mesma letra não diferem estatis ticamente, ao nivel de 5\% de probabilidade.

** = altamente significativo

ns = não significativo ao nível de $5 \%$ de probabilidade.

Os resultados do desdobramento dos graus de li berdade para altura entre espécie, são apresentados na Tabela 12. 
Tabela 12. Desdobramento dos graus de liberdade, para altura entre espécie, aos 13 meses de idade.

\begin{tabular}{lc}
\hline Espécie & Altura (m) \\
\hline E. grandis & $7,26 \mathrm{a}$ \\
E. urophylla & $6,04 \mathrm{~b}$ \\
\hline Teste F & $96,81 * *$ \\
DMS & 0,25 \\
\hline
\end{tabular}

OBS.: As médias seguidas pela mesma letra não diferem estatís ticamente, ao nivel de 5\% de probabilidade.

** = altamente significativo

CV (o) para: E. grandis $=11,35 ; E$. urophylla $=20,41$

Observa-se na Tabela 12 que o F revelou efeito altamente significativo para espécie, não se mostrando sig nificativo para os tratamentos dentro de espécie e nem para interação espēcie $x$ tratamento, ao nível de 5\% de probabilida de.

Verifica-se, assim, a continuidade da superioridade do $E$. grandis

Os dados de altura de plantas para os diferentes tratamentos evidenciam uma tendência de uniformização das plantas, caracterizando uma menor influência da èspécie no comportamento dessa variável, tendo em vista o valor de $\mathrm{F}$ obtido ser inferior, comparado à avaliação aos 6 meses de idade. 
Observou-se ainda, que os tratamentos com saco plástico, alturas e idades intermediárias, com as respectivas espécies, vêm ocupando posições de destaque, no que tange às alturas médias encontradas.

Os resultados obtidos concordam com os de BLAKE et alii (1988). Por outro lado, não concordam com os citados por LAUER (1987) que encontrou no tamanho de mudas um efeito significativo sobre a altura, depois de dois e três anos de idade.

- Eucalyptus grandis continuou demonstrando um melhor crescimento e uniformidade, apresentando um coeficiente de variação médio de 11,35\%, enquanto que o Eucalyptus urophylla apresentou crescimento e uniformidade inferiores, com um coeficiente de variação médio de $20,41 \%$.

Observou-se que no periodo de 6 a 13 meses de idade, o rítmo de crescimento das duas espécies estudadas foi mais intenso que nos 6 primeiros meses de idade. Para o Euca lyptus grandis, o pexíodo de 6 a 13 meses correspondeu a $65,84 \%$ do crescimento, e $34,16 \%$ nos 6 primeiros meses. para o Eucalyptus urophylla o segundo período considerado correspon deu a $66,89 \%$ do crescimento e $33,11 \%$ no primeiro período. Is to evidencia que as duas espécies recuperaram com mais intensidade a taxa de crescimento após o "choque" ocorrido durante - plantio. 


\subsubsection{Avaliação aos 37 meses de idade}

Nesta idade, são levados em consideração para efeito de análise a altura de plantas, DAP, ārea basal, volume cilindrico, bifurcação e plantas mortas.

A Tabela 13 apresenta os resultados das análises de variância dos parâmetros altura das árvores, diâmetro à altura do peito, área basal, volume cilíndrico percentagem de bifurcação e plantas mortas das espécies Eucalyptus grandis e Eucalyptus urophylla, submetidas aos diferentes tra tamentos aos 37 meses de idade.

Conforme observa-se na Tabela 13, o teste F pa ra o DAP revelou diferenças significativas entre os tratamentos, a 5\% de probabilidade, porém essas diferenças não foram detectadas pelo teste de Tukey, quando comparam as médias dos tratamentos ao mesmo nível de probabilidade. Para a área basal o teste $F$ não revelou diferenças significativas entre tratamentos.

Nas análises com o desdobramento dos graus de liberdade, apresentada na Tabela 14, o valor de $F$ para os dois parâmetros mostrou um efeito altamente significativo para a espécie, não evidenciando efeito para os tratamentos e nem para a interação espécie x tratamento. Na comparação das médias entre as espécies, o teste de Tukey detectou diferenças significativas ao nível de 5\% de probabilidade, evidenciando a supremacia de crescimento do Eucalyptus grandis. 


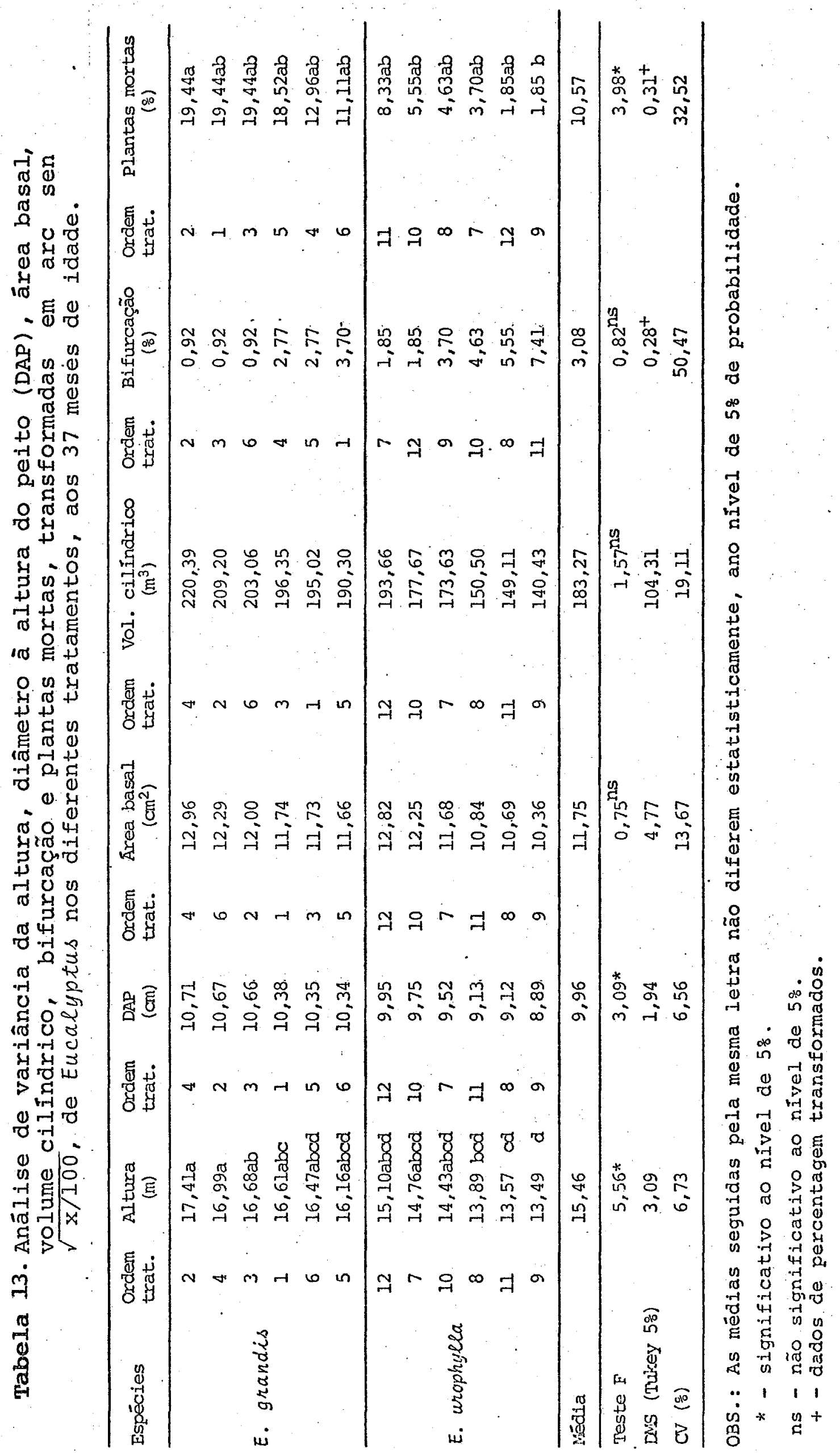


As Figuras 6, 7 e 8 ilustram, respectivamente, - comportamento daș espécies de eucaliptos em relação à altura mēdia nos diferentes tratamentos, altura e DAP médios, e área basal e volume cilindrico, aos 37 meses de idade.

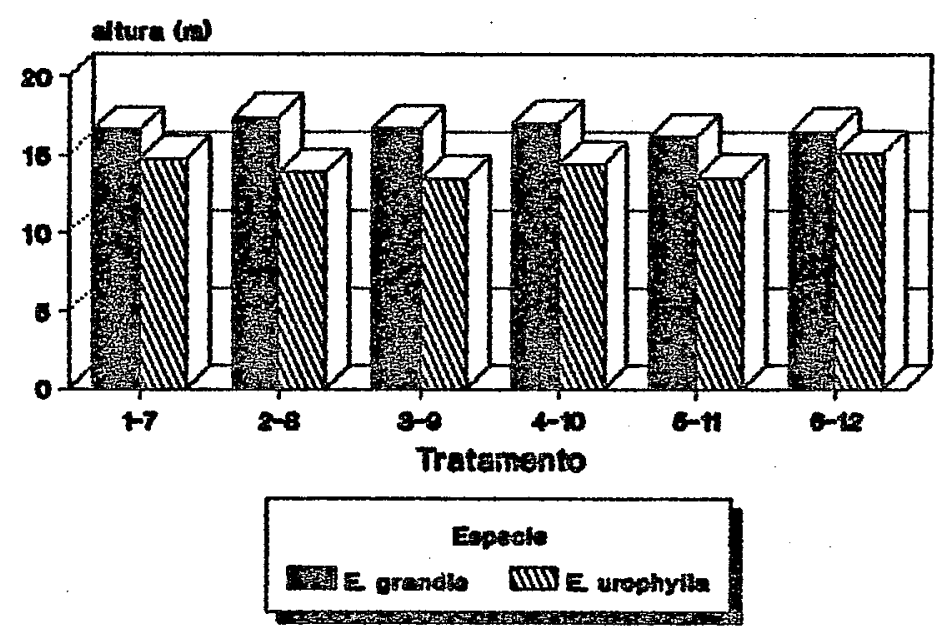

Figura 6. Altura média das espécies de eucaliptos nos diferen tes tratamentos, aos 37 meses de idade.

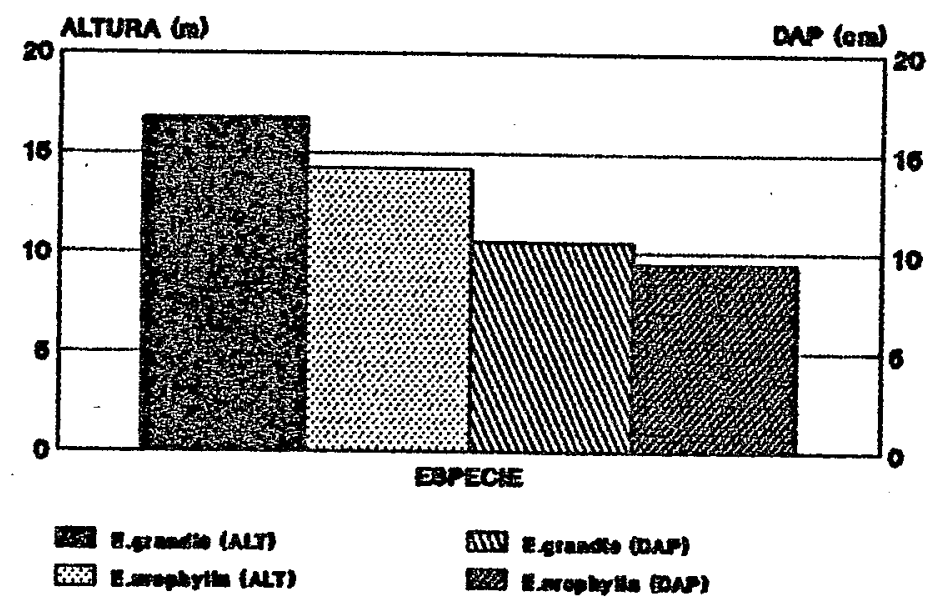

Figura 7. Altura e DAP médios das espēcies de eucaliptos, aos 37 meses de idade. 


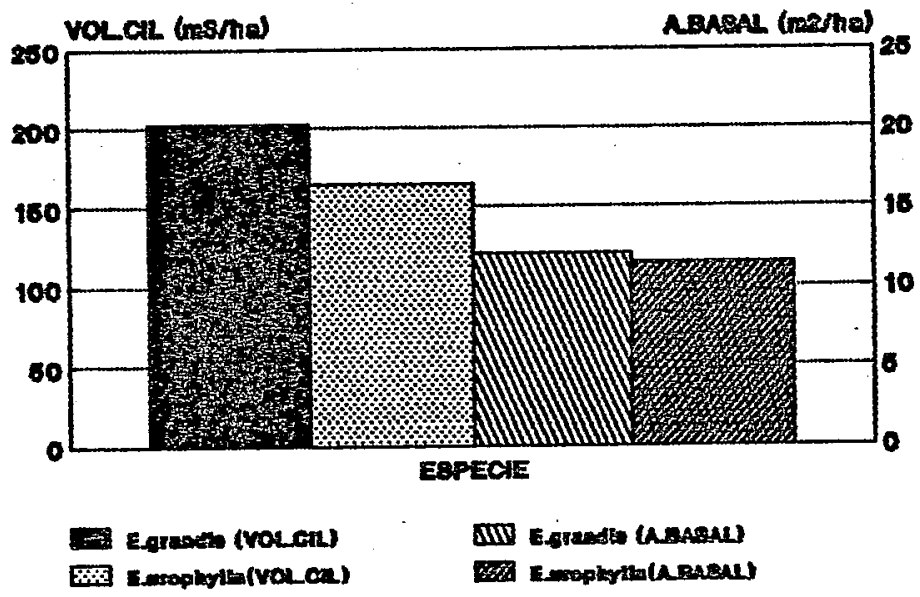

Figura 8. Área basal e volume cilíndrico médios das espécies de eucaliptos, aos 37 meses de idade. 
Com relação à altura, o teste $\mathrm{F}$ revelou diferenças significativas entre tratamentos, ao nivel de 5\% de probabilidade. Na comparação das médias, o teste de Tukey de tectou diferenças entre tratamentos no mesmo nível de probabị lidade, porém com uma menor variação entre os tratamentos, quan do comparada com as análises anteriores. Isto nos indica uma provável tendência de maior uniformidade no crescimento em al tura das duas espēcies submetidas aos diferentes tratamentos.

No Eucalyptus grandis, o tratamento 6 formado por recipiente saco plástico, aos 37 meses de idade, passou a ocupar a penúltima posição das médias. Nas anālises anteriores, o mesmo ocupou as primeiras posições das médias, embo ra em nenhuma das análises se tenha detectado diferença estatística entre os tratamentos dentro da mesma éspécie. Enquan to que no Eucalyptus urophylla, o tratamento 12 , formado pelo recipiente saco plástico, permaneceu ocupando as primeiras po sições das médias.

Os tratamentos 8, 9 e 11 do Eucalyptus urophylla foram inferiores aos demais tratamentos, detectados pe lo teste de Tukey.

As variáveis altura, DAP, área basal e sobrevi vência são diretamente relacionadas com a produtividade em vo lume cilinarico. 
Na análise de variância do volume cilindrico e de bifurcação, o teste $F$ não revelou diferenças significativas entre os tratamentos, a 5\% de probabilidade. Por outro lado, para plantas mortas, o teste $F$ revelou diferença significativa entre os tratamentos, tambēm detectada pelo teste de Tukey, quando da comparação das médias dos referidos tratamen tos, ao nivel de $5 \%$ de probabilidade.

Os resultados do desdobramento dos graus de liberdade para espécie são apresentados na Tabela 14. 
Tabela 14. Resultados do desdobramento dos graus de liberdade para altura, DAP, área basal, volume cilindrico, bifurcação e plantas mortas, com percentuais transformados em arc sen $\sqrt{\mathrm{x} / 100}$, de Eucalyptus aos .37 meses de idade.

\begin{tabular}{|c|c|c|c|c|c|c|}
\hline $\begin{array}{l}\text { Variāveis } \\
\text { Espēcies }\end{array}$ & $\begin{array}{l}\text { Altura } \\
\text { (m) }\end{array}$ & $\begin{array}{l}\text { DAP } \\
(\mathrm{cm})\end{array}$ & $\begin{array}{c}\text { Área basal } \\
\left(\mathrm{m}^{2} / \mathrm{ha}\right)\end{array}$ & $\begin{array}{l}\text { Volume } \\
\text { cilind. } \\
\left(\mathrm{m}^{3} / \mathrm{ha}\right)\end{array}$ & $\begin{array}{c}\text { Bifurcação } \\
\text { (\%) }\end{array}$ & $\begin{array}{l}\text { Plantas } \\
\text { mortas } \\
\quad(\%)\end{array}$ \\
\hline E. grandis & $16,72 \mathrm{a}$ & $10,52 a$ & $12,06 \mathrm{a}$ & $202,39 a$ & $2,00 \mathrm{a}$ & $16,82 \mathrm{a}$ \\
\hline E. urophylla & $14,21 \mathrm{~b}$ & $9,39 \mathrm{~b}$ & $11,44 a$ & $164,17 \mathrm{~b}$ & $4,16 a$ & $4,32 \mathrm{~b}$ \\
\hline Teste F & $52,59 * *$ & $26,90 * *$ & $1,36^{\mathrm{ns}}$ & $10,66 * *$ & $3,43^{\mathrm{ns}}$ & $35,51 * *$ \\
\hline DMS (Tukey 5\%) & 0,72 & 0,45 & 1,11 & 24 & $0,06^{+}$ & $0,07^{+}$ \\
\hline
\end{tabular}

Obs.: As mëdias seguidas pela mesma letra não diferem estatís ticamente, ao nivel de 5\% de probabilidade.

* * : altamente significativo

ns : não significativo ao nível de 5\%

$+\quad$ : dados de percentagem transformados

$\mathrm{CV}$ altura (\%): E. grandis $=4,68 ; . E$. urophylla $=7,91$

CV DAP (\%): $\quad$ E. grandis $=.6,04 ; E$. urophylla $=6,92$

CV a. basal (\%): E. grandis $=12,18 ; E$. urophylla $=13,09$

CVvol. cil. (\%): E. grandis $=17,56 ; E$. urophylla $=20,48$

CV bifurcação (o) $: E$. grandis $=90,75 ; E$. urophylla $=40,24$

CV plantas mortas (o): E. grandis $=47,98 ; E$. urophylla $=35,76$

De acordo com a Tabela 14, O teste F revelou um efeito altamente significativo para a espécie nas variāveis altura, DAP, volume cilíndrico e plantas mortas, não revelando efeito para os tratamentos dentro de espécie e nem para a interação espēcie $\mathrm{x}$ tratamento, enquanto que para área ba- 
sal e bifurcação o teste $\mathrm{F}$ não revelou diferenças significatị vas ao nível de 5\% de probabilidade.

Os coeficientes de variação experimental das espécies para a variável altura, apresentaram uma diminuição significativa em relação às avaliações anteriores, demonstran do uma tendência de melhor uniformidade, conforme aumentava o crescimento das plantas.

Os coeficientes de variação experimental das variáveis DAP e área basal, apresentaram uma diferença muito pequena entre as espécies, demonstrando assim, menor variação na uniformidade de crescimento nessas duas variáveis.

Sendo a área basal uma variável dependente do DAP e sofrendo efeitos da sobrevivência das ārvores, verifica-se que a influência da sobrevivência das espécies foi marcante na determinação dessa variável, haja vista o resultado de sua análise não ter revelado diferença estatística signifi cativa entre as espécies, o que não ocorreu para o DAP.

o volume cilindrico, sendo uma caracteristica de crescimento composta e sofrendo os efeitos de plantas mortas, deve ter um maior nưmero de repetições para a comparação da eficiência estatística nesse tipo de experimentação. Como tarabēm foi a caracteristica que mostrou maior erro experimen tal, provavelmente. foi a causa da não deteç̧ão de variações. 
- comportamento de Eucalyptis grandis e Eucalyptus urophylla, no Estado de são Paulo, verificaram que o $E$. grandis é a espé cie de maior produtividade, porém mais sujeita à mortalidade, devido à seca edáfica. O E. urophylla apresentou um comportą mento favorável com relação à resistência à seca.

$$
\text { BALLONI (1982) verificou aos } 2,5 \text { e } 4 \text { anos de }
$$
idade, uma alta mortalidade de árvores de Eucalyptus grandis (Coff's Harbour) e Eucalyptus saligna (Itatinga), respectivamente. A morte das árvores ocorreram devido a deficiência

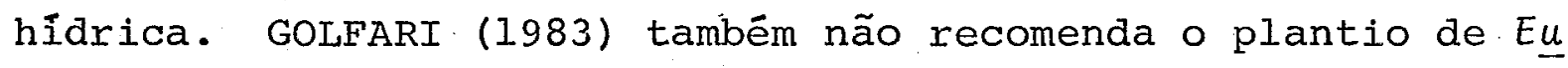
calyptus grandis, de procedência Coff's Harbour, em regiões tropicais com periodo de seca prolongado, por ser oriundo de uma ārea com chuvas uniformemente distribuías e com ausência. de déficit hídrico.

Ainda, STAPE et alii (1989) encontraram no Eucalyptus grandis, procedente de Boa Esperança do Sul-SP/Pomar de Semente de Muda, a espécie de maior produtividade, plantada em Areia Quartzosa, em São Paulo. 


\subsection{Descrigão das RAIZES}

\section{a) Eucalyptus grandis (saco plästico e tubete)}

Árvore dominante : a árvore oriunda de muda produzida em saco plástico apresentou uma simetria mais uniforme das raízes laterais e sem evidências de qualquer tipo de deformação, com uma rajz pivotante bastante vigorosa (Figun ra 9). A oriunda de tubete mostrou um sistema de raízes late rais de segunda e terceira ordens, mais abundante, e uma sime tria com massa densa de raizes orientadas bilateralmente de forma oposta. Observou-se formação de bifurcação da raiz pivotante um pouco abaixo do ponto de saída das raízes laterais (Figura 10).

Árvore média: a árvore oriunda de saco plástico apresentou um sistema de raizes laterais mais abundante, com uma simetria melhor distribuída, porém com evidências de pequenas deformações de direcionamento em algumas raízes secundārias e uma constrição em seu sistema, porém com boa formação de raiz pivotante (Figura 11). A ārvore oriunda de tubete mostrou um sistema de raizes laterais bastante deficiente em volume, com uma simetria mal-balanceada, e uma raiz pivotante bifurcada e raquitica (Figura 12). 
.55 .

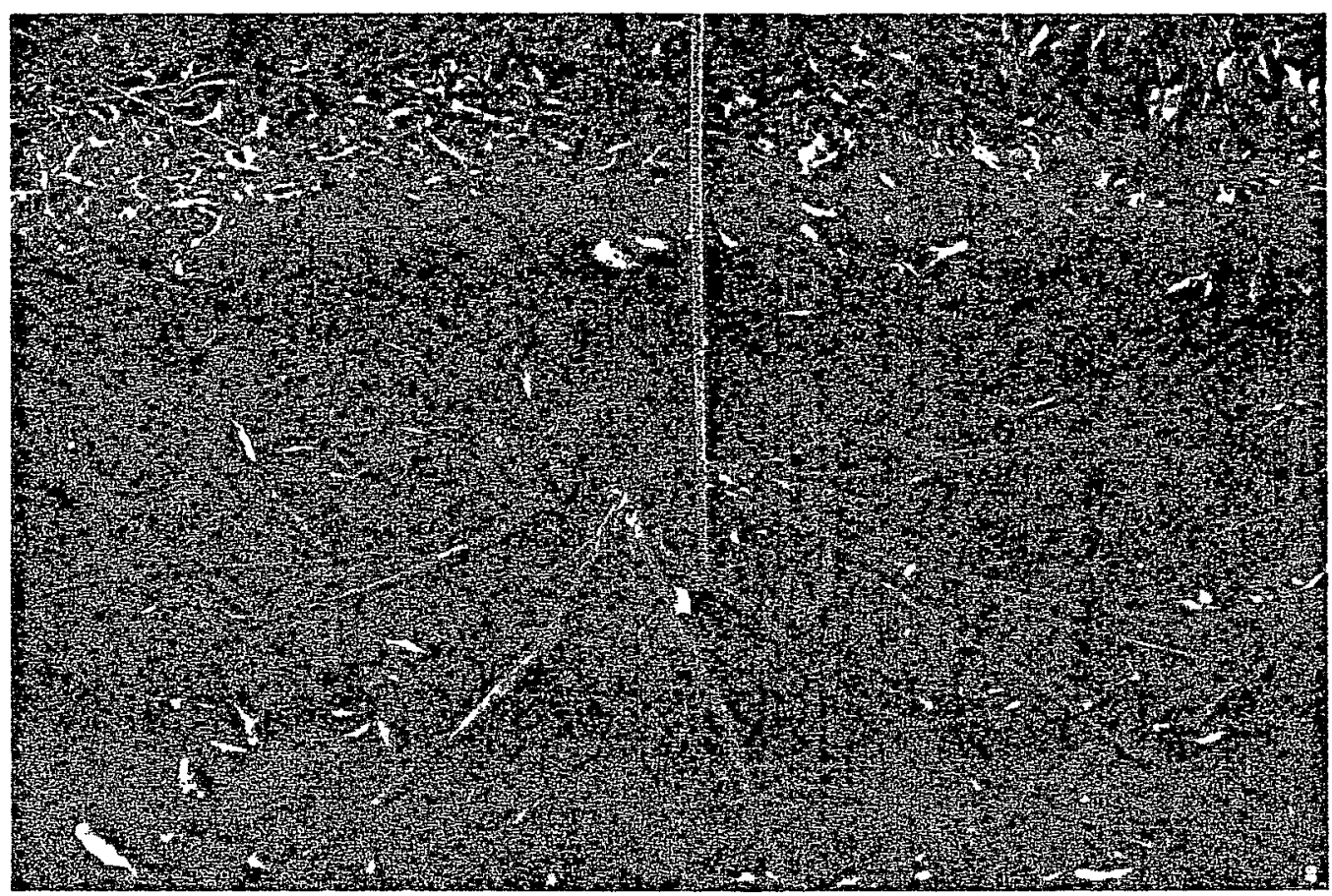

Figura 9. Raîzes de ärvore dominante de Eucalyptus grandis, aos 39 meses de idade, oriunda de muda produzida em saco plástico. 
.56 .

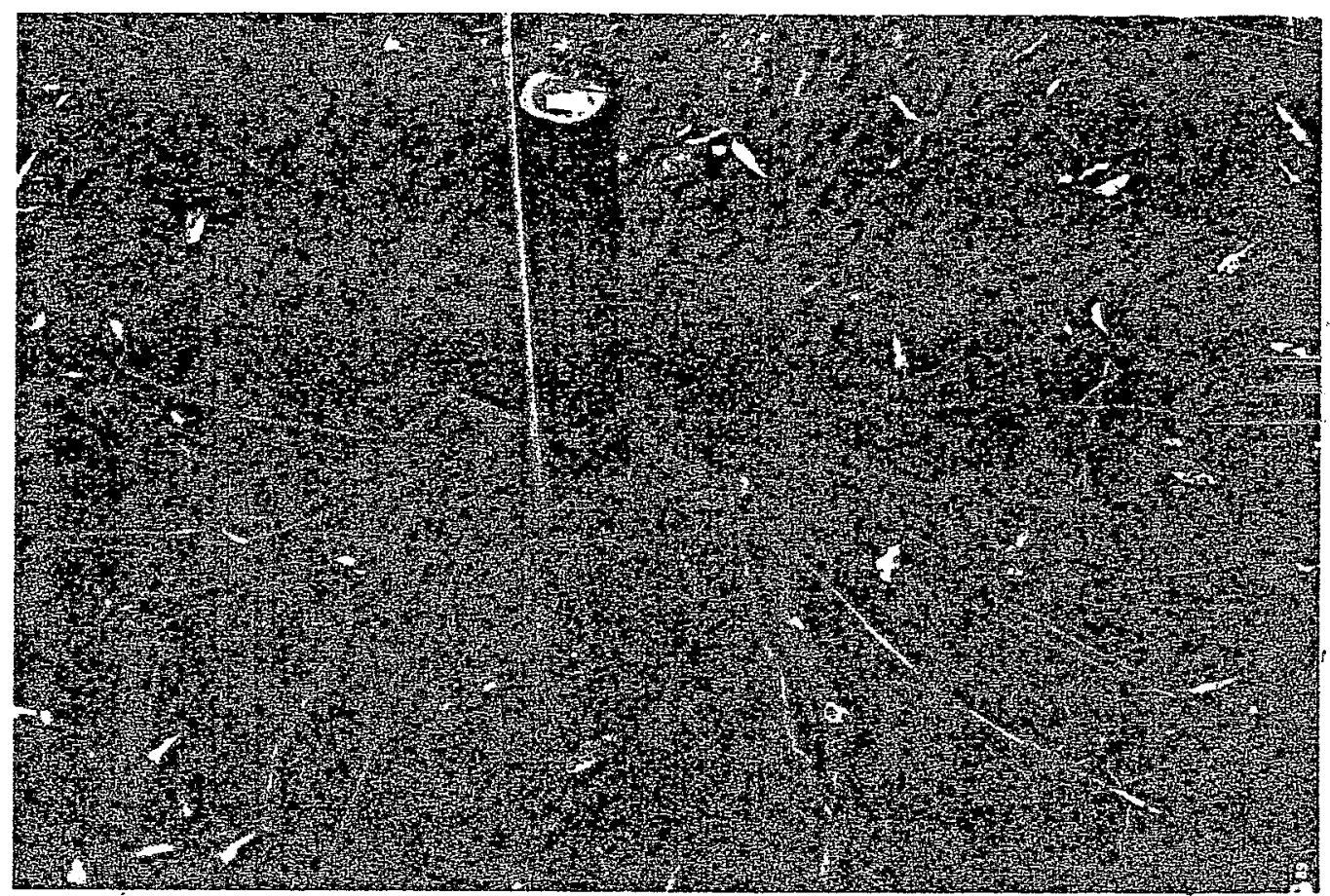

Figura 10. Raîzes de ärvore dominante de Eucalyptus grandis, aos 39 meses de idade, oriunda de muda produzida em tubete. 
.57.

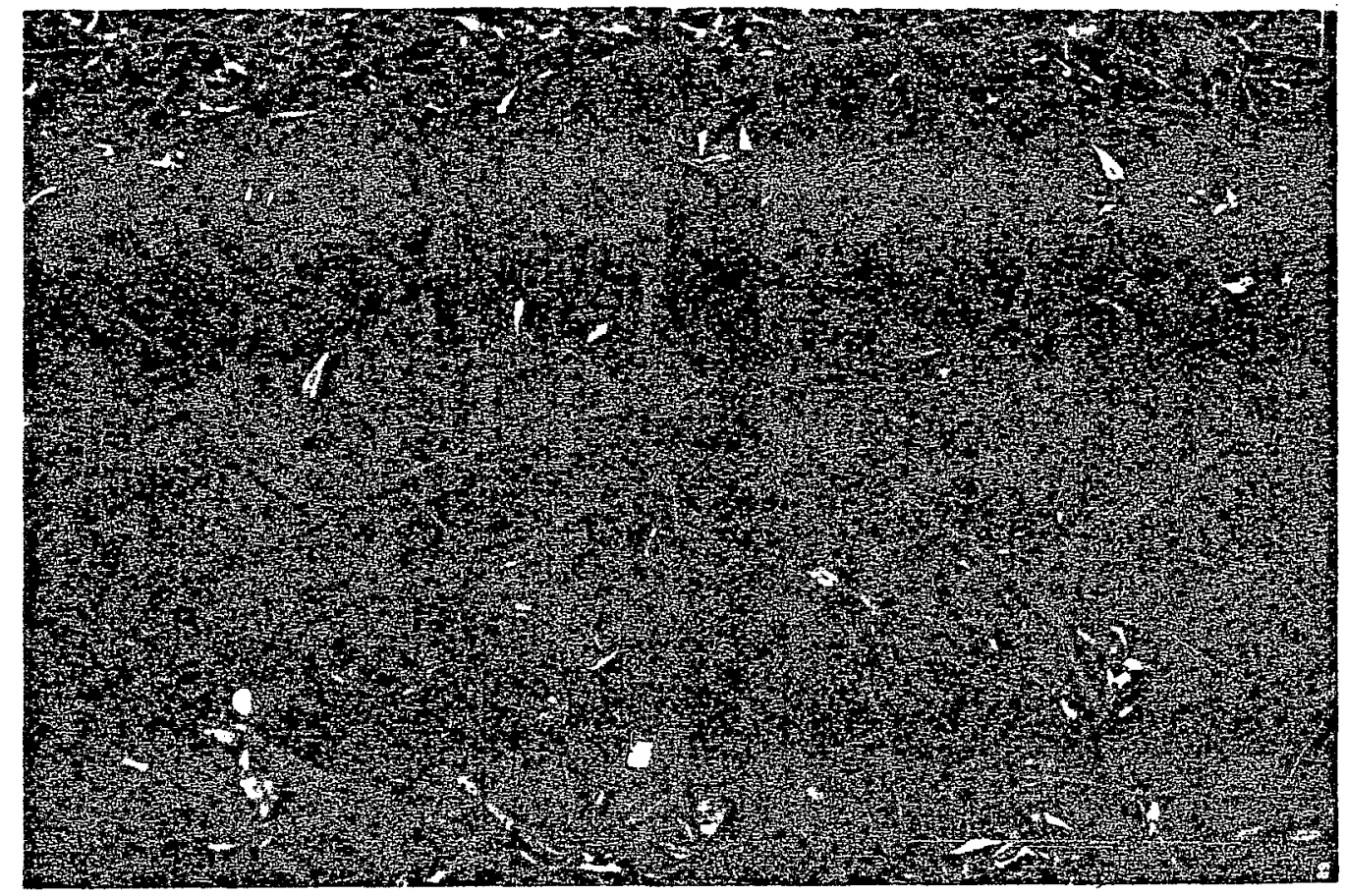

Figura 11. Raízes de árvore média de Eucalyptus grandis, aos 39 meses de idade, oriunda de muda produzida em sa co plástico. 


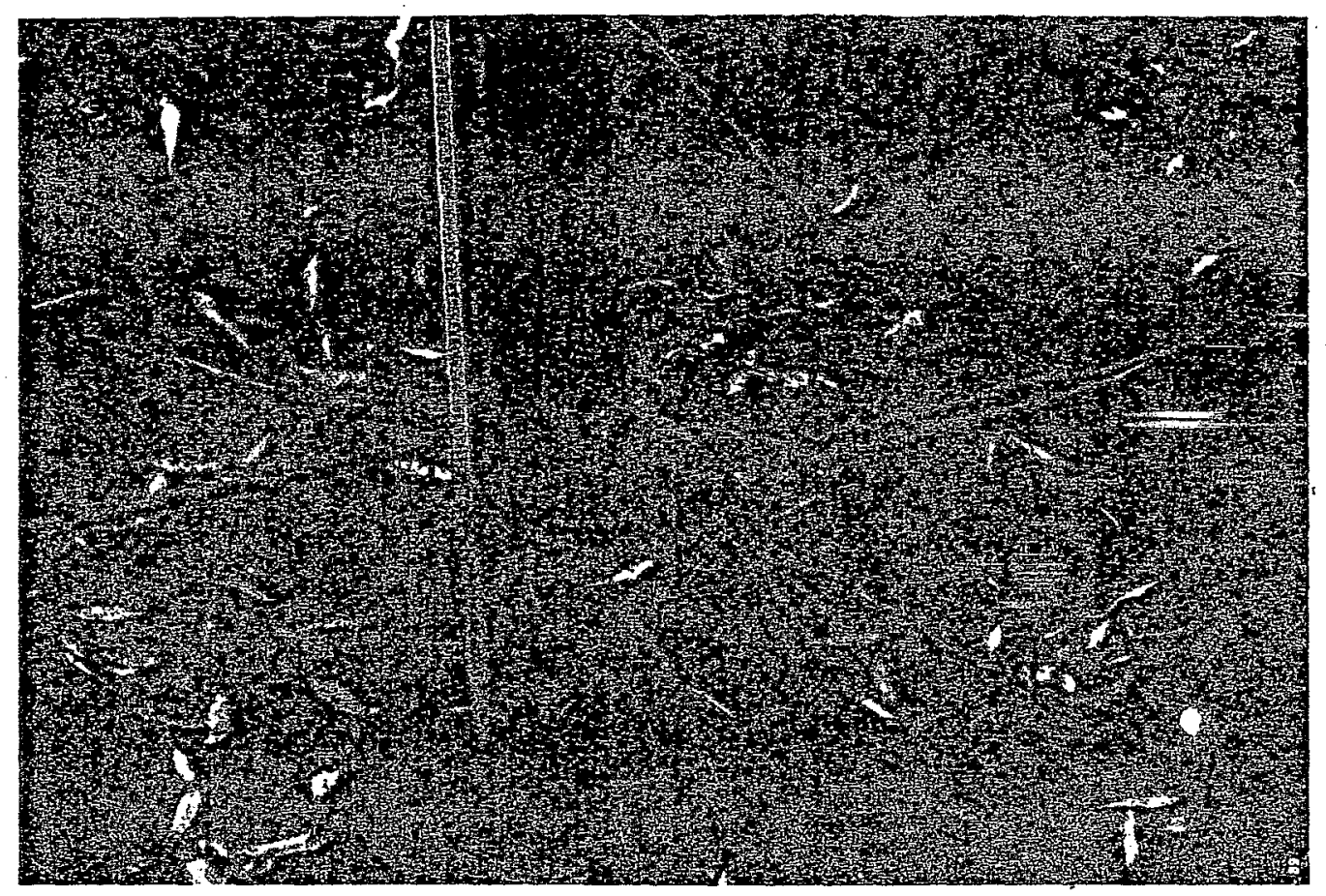

Figura 12. Raízes de ārvore média de Eucalyptus grandis, aos 39 meses de idade, oriunda de muda produzida em tu彑 bete. 
Árvore dominada: a árvore oriunda de saco plás tico mostrou constrição de raízes laterais, mas com uma. simetria bem uniforme e uma certa abundância de raízes de terceira e quarta ordens. A raiz pivotante apresentou uma forte curvatura em forma de "L" nos $30 \mathrm{~cm}$ de profundidade, aproximadamente (Figura 13). A árvore oriunda de tubete : apresentou uma simetria mal-balanceada de raỉzes laterais, com uma notável deficiência de raízes de segunda e terceira ordens, e uma evidente bifurcação da raiz pivotante desde a camada superficial do solo em forma de " $h$ " (Figura 14).

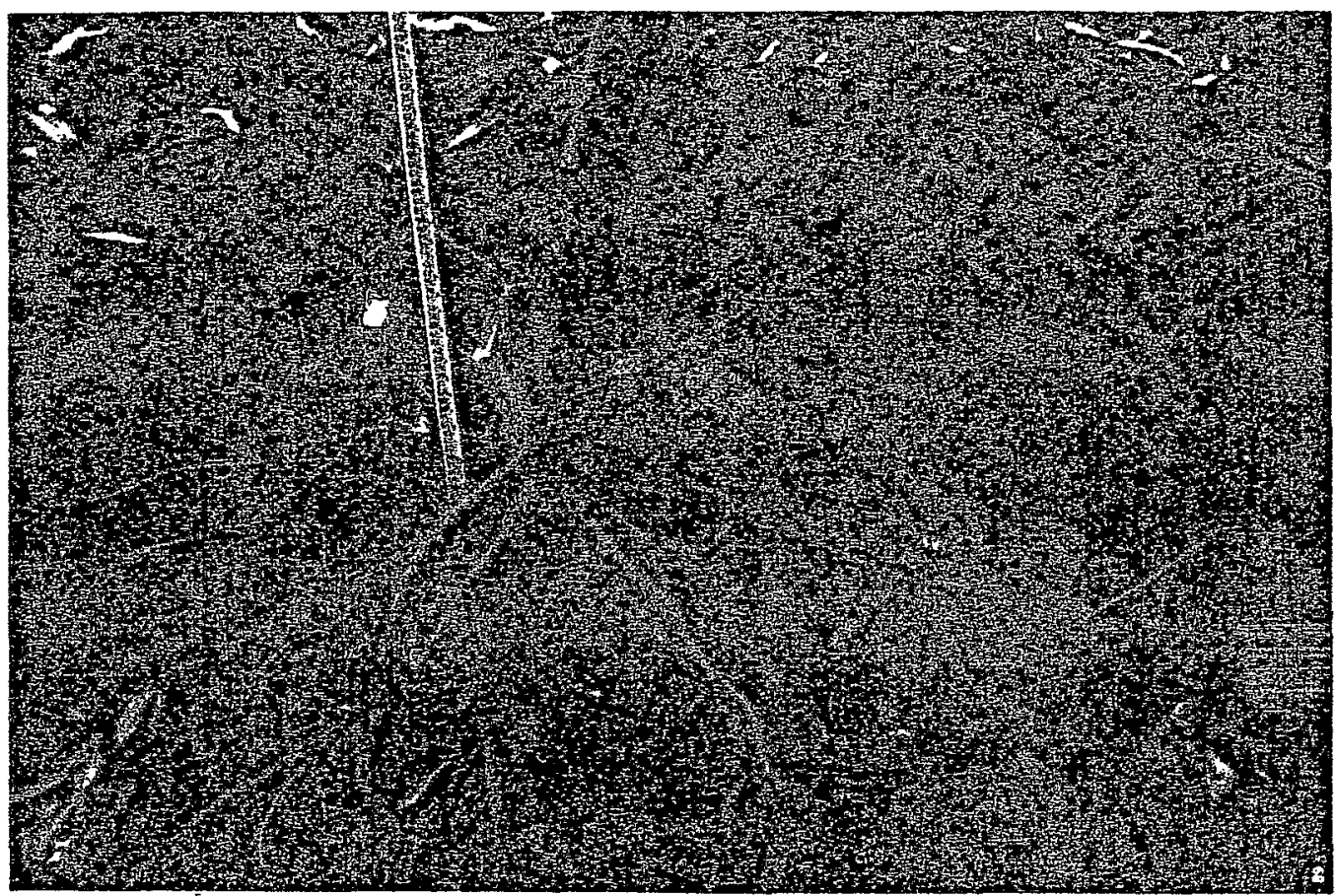

Figura 13. Raízes de ärvore dominada de Eucalyptus grandis, aos 39 meses de idade, oriuñda de muda prodüzida em saco plástico. 


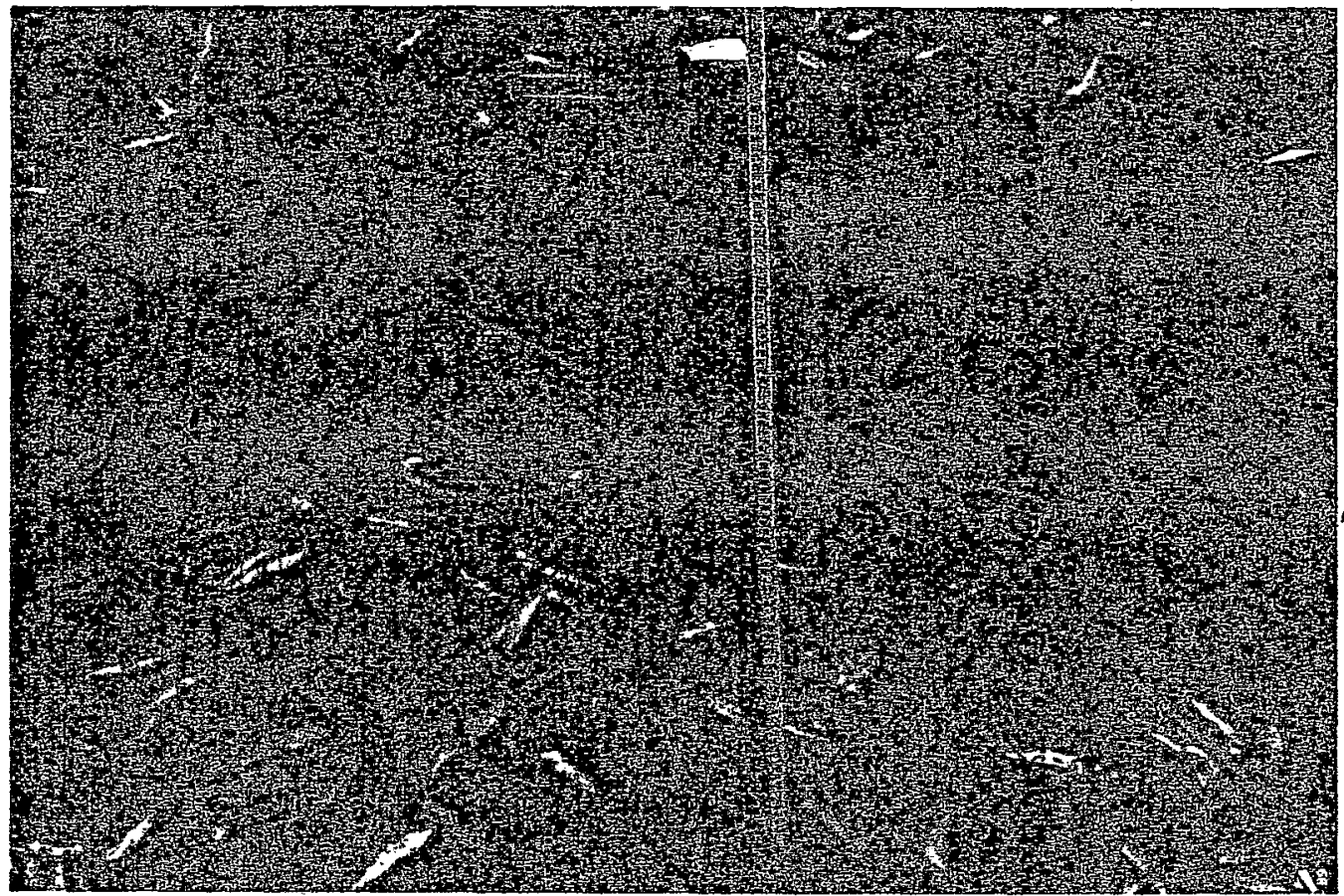

Figura 14. Raízes de ärvore dominada de Eucalyptus grandis, aos 39 meses de idade, oriunda de muda produzida em tubete.

Arvore morta: a árvore oriunda de saco plástico apresentou uma simetria de raízes laterais bastante irregu lar com evidentes deformações e total ausência de raízes de terceira e quarta ordens, e uma raiz pivotante bifurcada e tortuosa (Figura 15). A árvore oriunda de tubete mostrou uma simetria das raízes laterais mais uniforme e total ausência 
de raizes de terceira e quarta ordens e uma raiz pivotante ví gorosa, porēm apresentando uma tortuosidade e bifurcação, bas tante evidente (Figura 16).

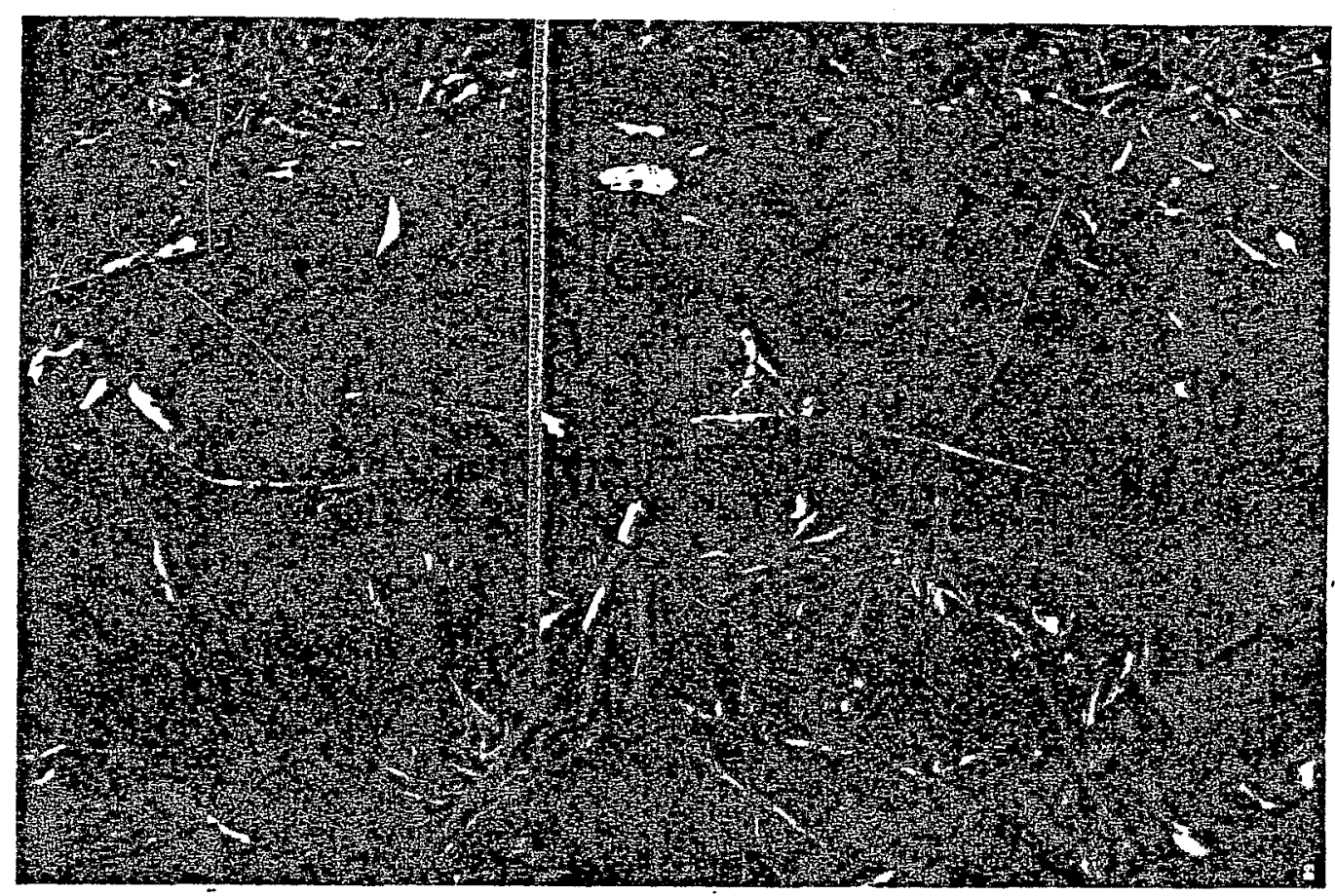

Figura 15. Raízes de ärvore morta de Eucalyptus grandis, aos 39 meses de idade, oriunda de muda produzida em sa co plástico. 


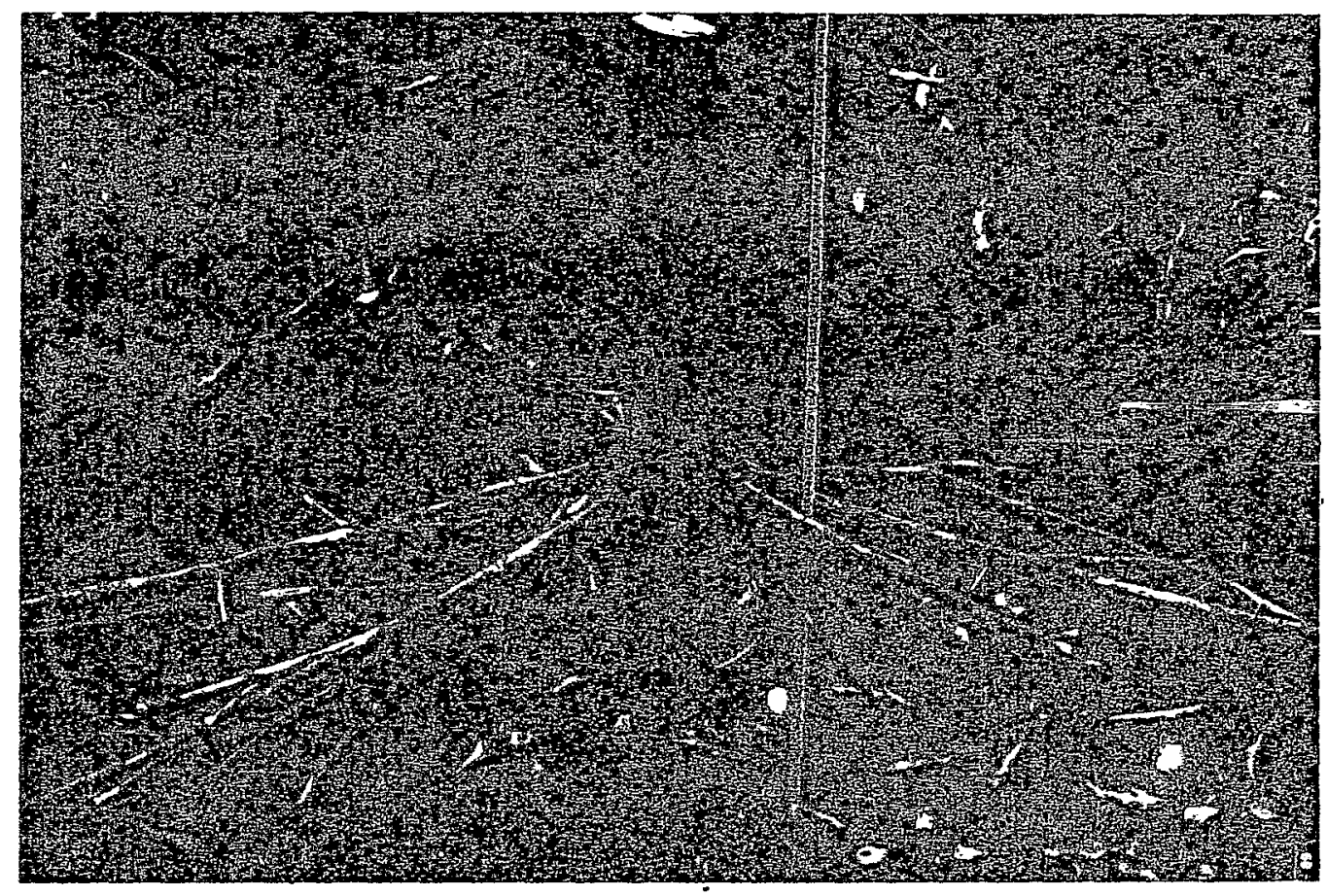

Figura 16. Raízes de árvore morta de Eucalyptus grandis, aos 39 meses de idade, oriunda de muda produzida em tú bete. 


\section{b) Eucalyptus urophylla (saco plástico e tube- te)}

Árvore dominante: a árvore oriunda de muda pro duzida em saco plástico apresentou uma simetria relativamente bem balanceada das raízes laterais primárias, sem abundância de raízes de segunda e terceira ordens, e sem evidência de de formação, com a raiz pivotante não muito expressiva (Figura 17). A árvore oriunda de tubete apresentou sistema de raizes laterais mais abundante, porém com uma simetria de raízes prí márias mal-balanceadas, e evidência de formação de raízes de "compensação", observando-se também fortes curvaturas de raízes laterais primárias, uma raiz pivotante bastante vigorosa (Figura 18).

Árvore média: a árvore oriunda de saco plástico apresentou um sistema de raízes laterais bastante deficien te,com raízes laterais primárias bastante dispersas e uma simetria muito irregular, com evidência de bifurcação de raiz pivotante (Figura 19). A árvore oriunda de tubete apresentou um sistema radicular lateral mais volumoso, com uma simetria mal-balanceada, e algumas raízes laterais com deformações de "curvatura" para o lado e para baixo, com evidência de formação de raiz de "compensação", e raiz pivotante mal-formada e deficiente (Figura 20). 


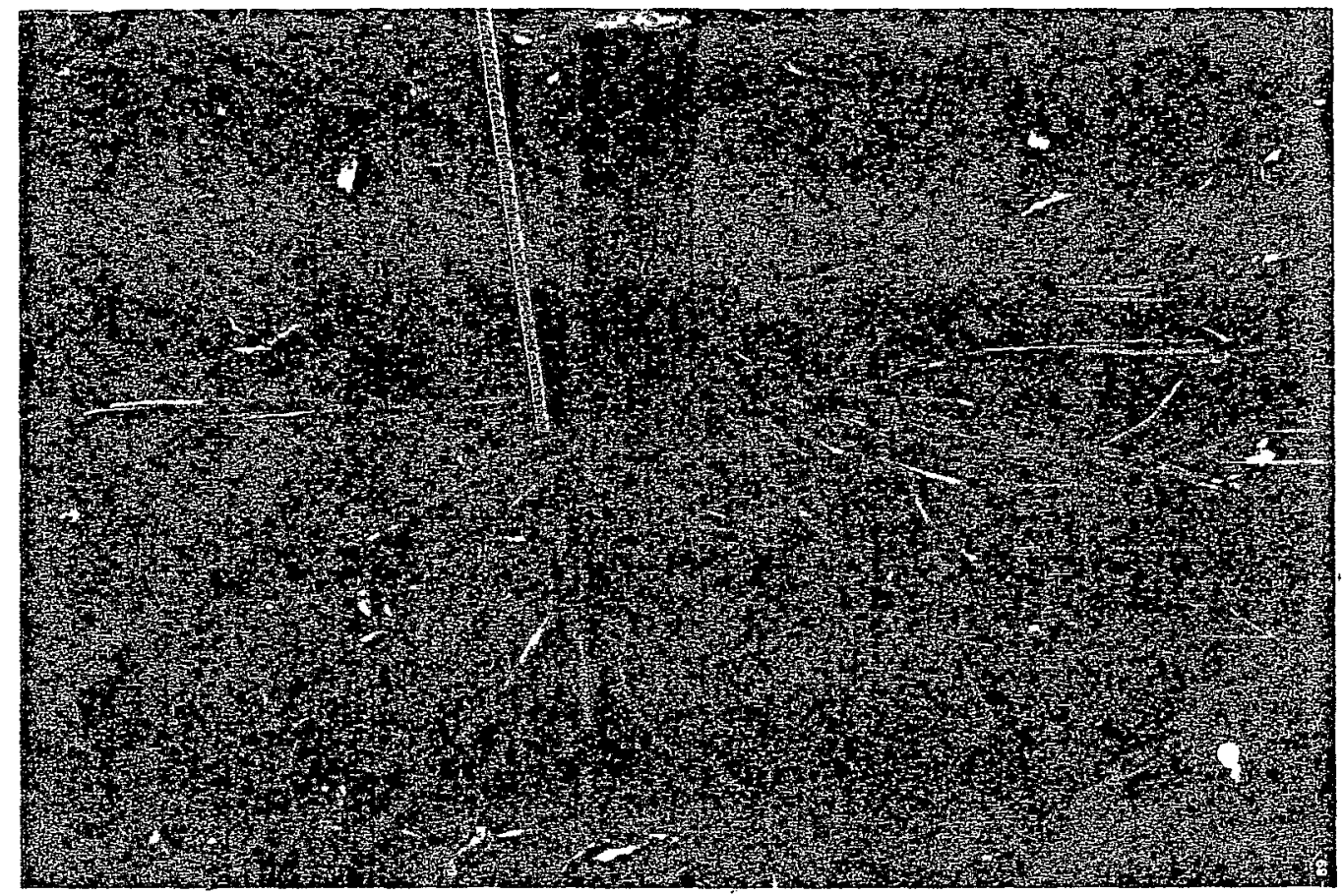

Figura 17. Raízes de árvore dominante de Eucalyptus urophylla, aos 39 meses de idade, oriunda de muda produzida em saco plástico. 
.65.

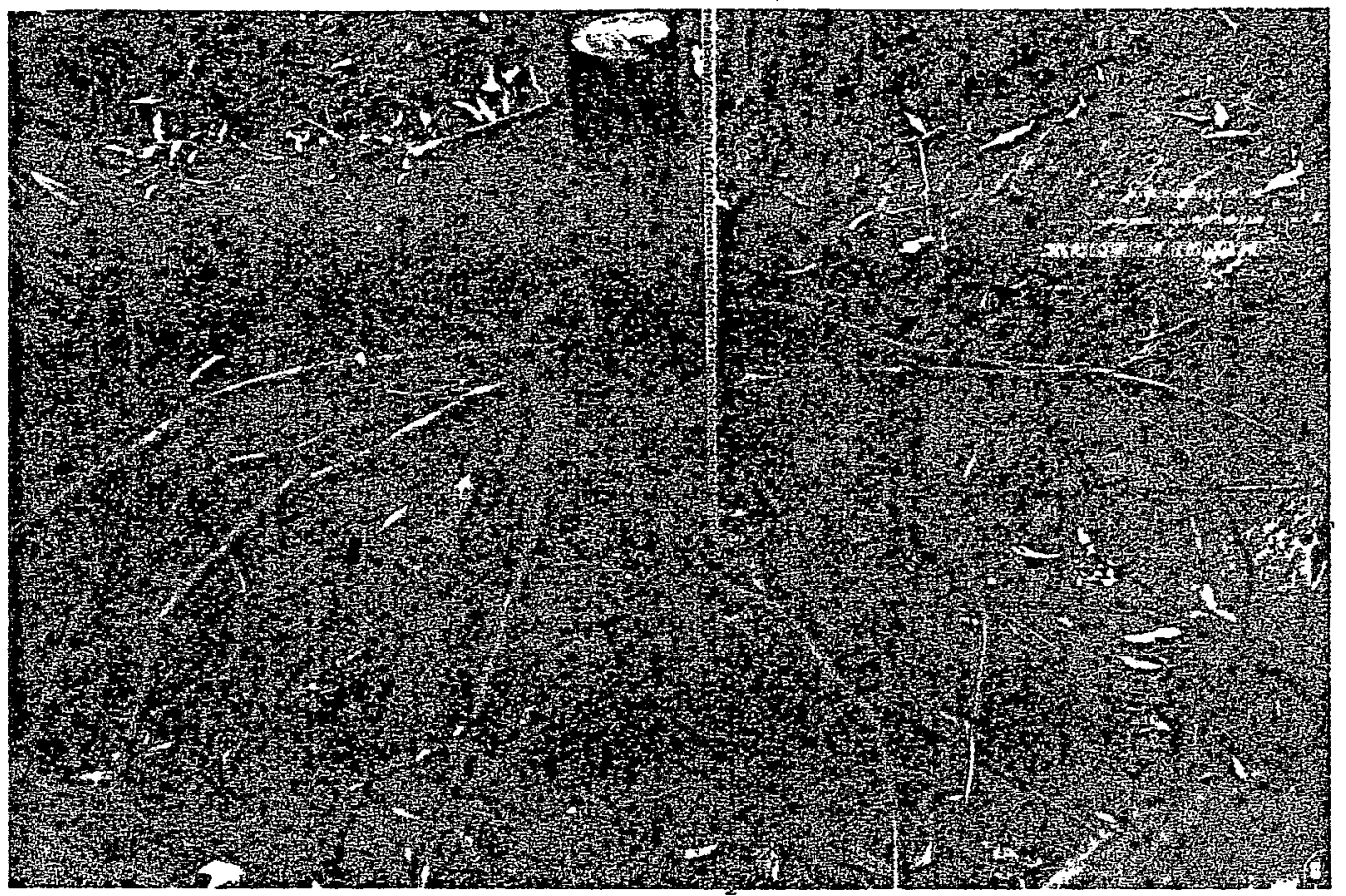

Figura 18. Raízes de ärvore dominante de Eucalyptus urophylla, aos 39 meses de idade, oriunda de muda produzida em tubete. 
.66 .

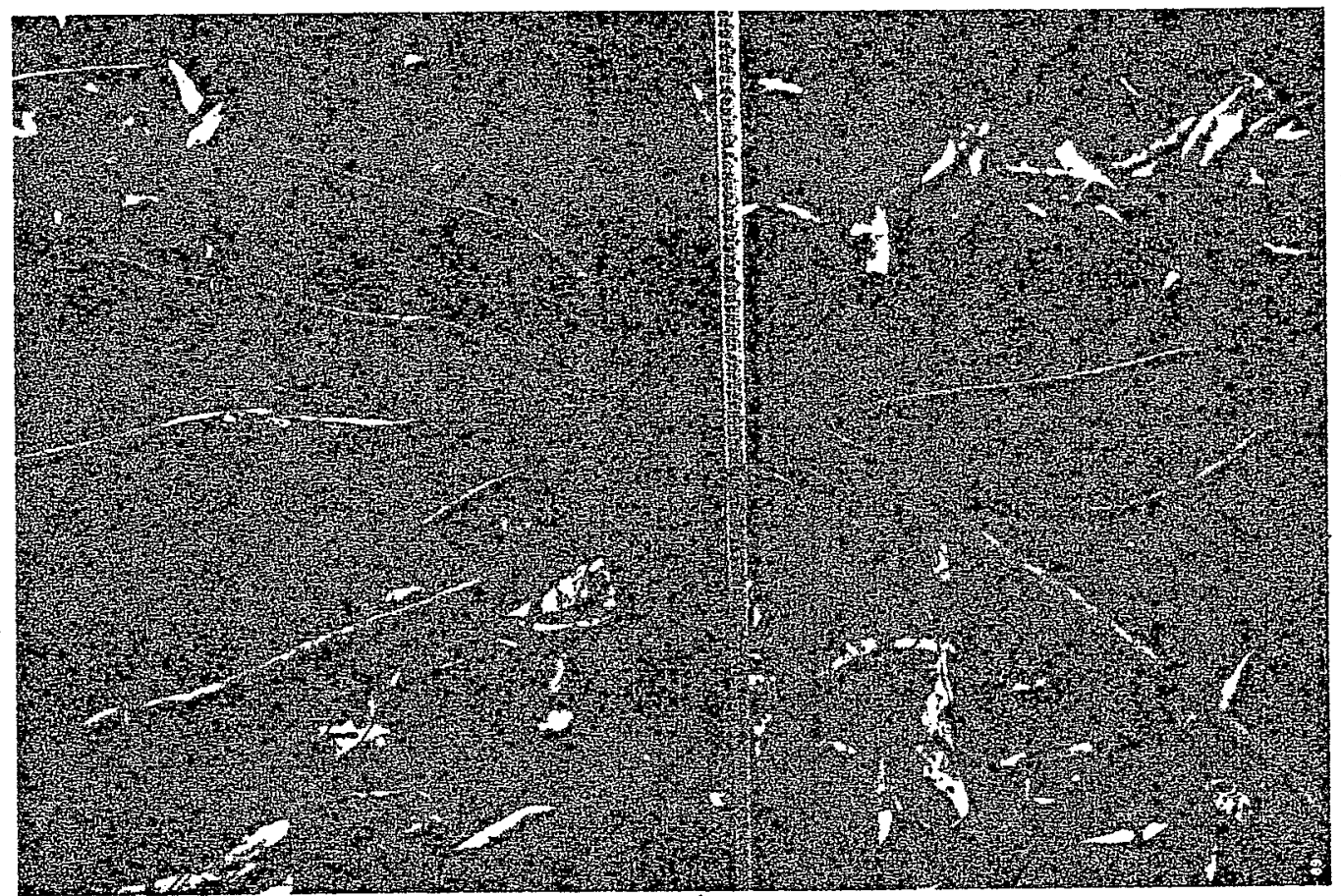

Figura 19. Raizes de ārvore média de Eucalyptus urophylla, aos 39 meses de idade, oriunda de muda produzida em saco plástico. 
.67.

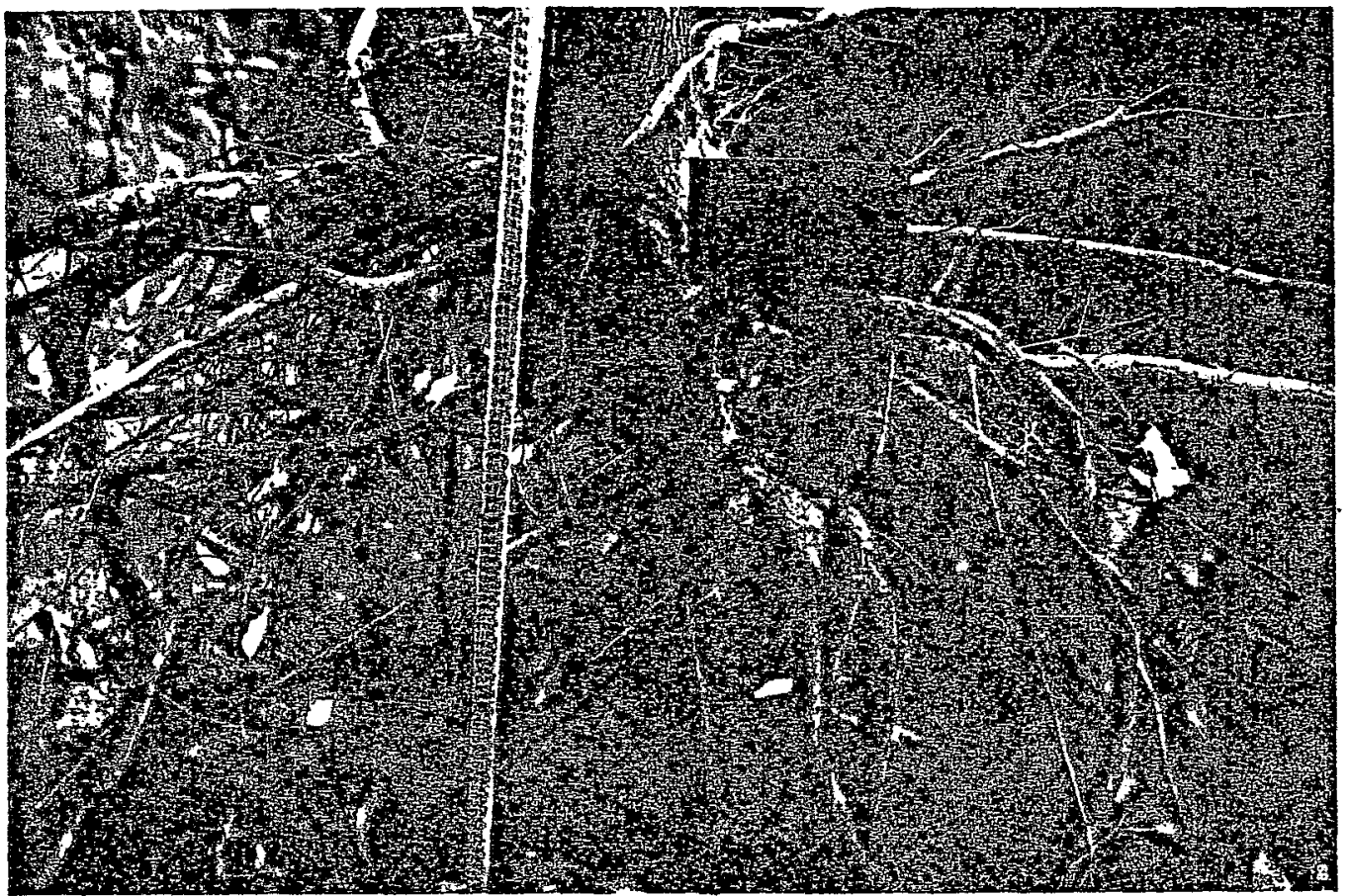

Figura 20. Raízes de ārvore média de Eucalyptus urophylla, aos 39 meses de idade, oriunda de muda produzida em tubete. 
Arvore dominada: a ārvore oriunda de saco plás tico apresentou um sistema de raízes laterais de primeira e segunda ordens bastante deficiente, com simetria mal-balancea da, uma constrição do sistema radicular bastante evidente e uma raiz pivotante trifurcada (Figura 21). A árvore oriunda de tubete também apresentou um sistema radicular bastante de ficiente, com raízes laterais primárias muito finas e com pou cas raízes de segunda ordeme uma raiz pivotante tortuosa (Figura 22).

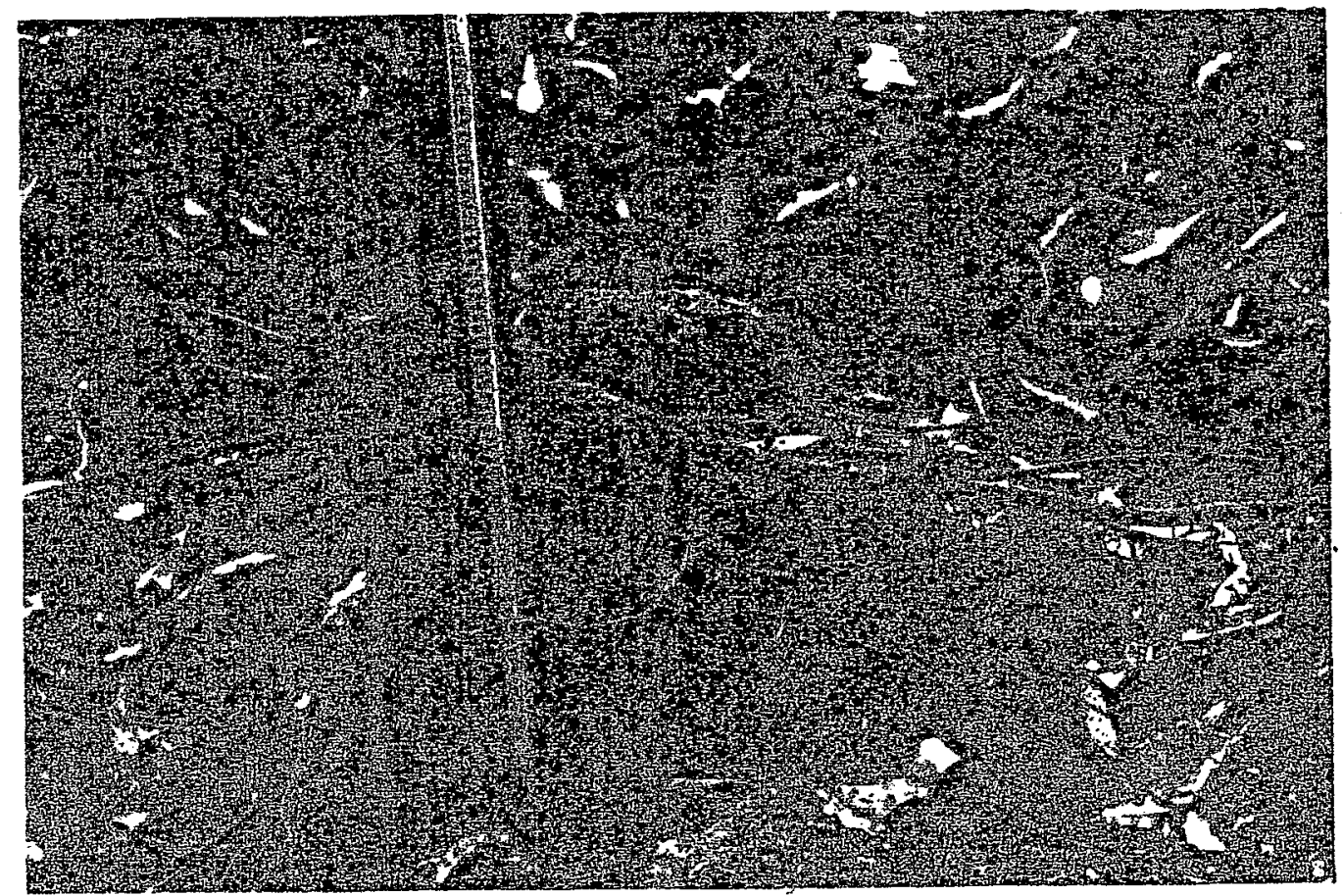

Figura 21. Raizes de árvore dominada de Eucalyptus urophylla, aos 39 meses de idade, oriunda de muda produzida em saco plástico. 


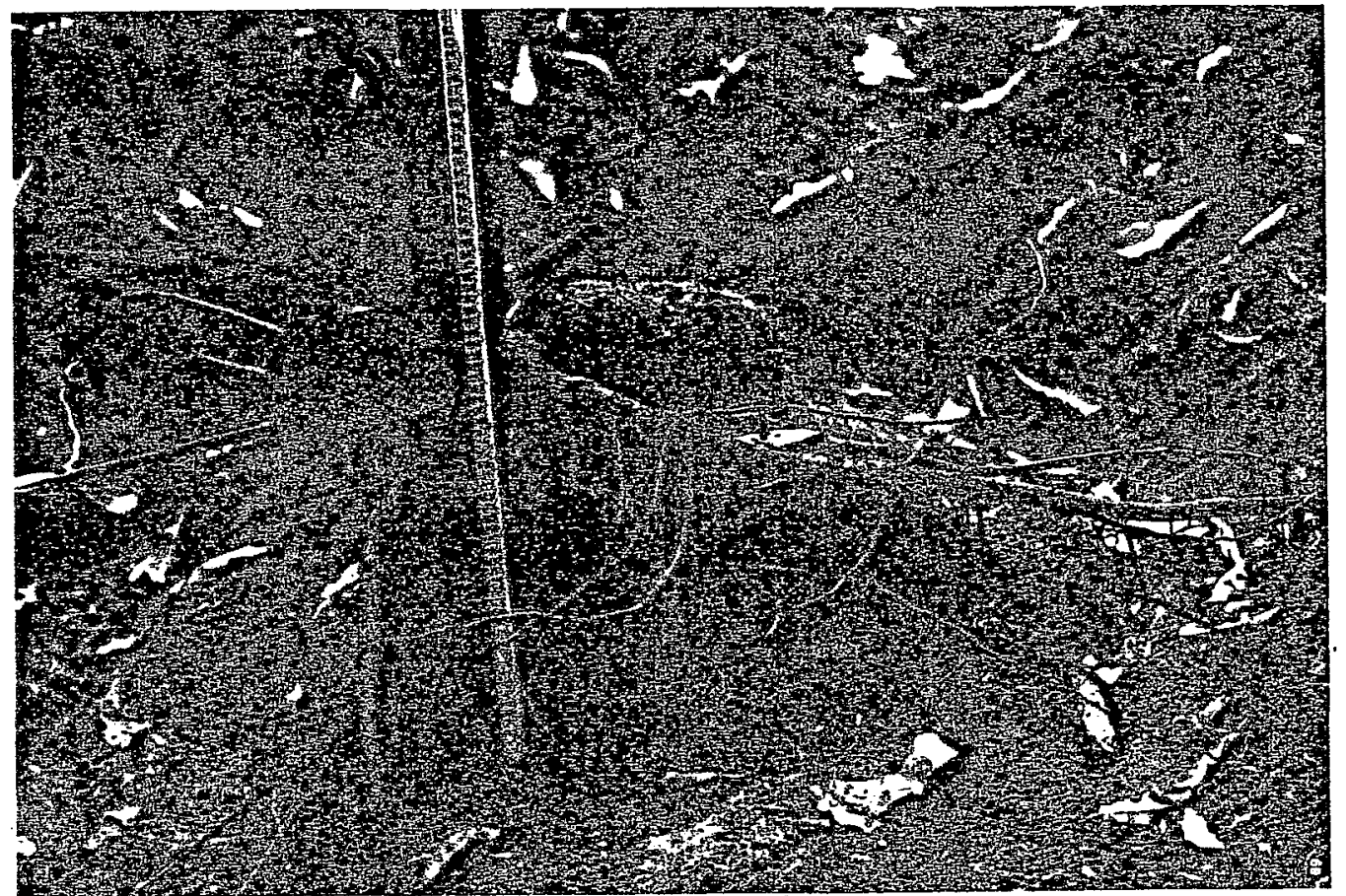

Figura 22. Raízes de ärvore dominada de Eucalyptus urophylla, aos 39 meses de idade, oriunda de muda produzida em tubete.

Árvore morta: a árvore oriunda de saco plästico mostrou um sistema de raízes laterais primārias bastante vigoroso, com uma simetria bem balanceada, porém com uma raiz pivotante bastante raquítica e bifurcada (Figura 23). A árvo re oriunda de tubete apresentou um sistema de raizes laterais evidente com simetria mal-balanceada e total ausência de raiz pivotante (Rigura 24). 


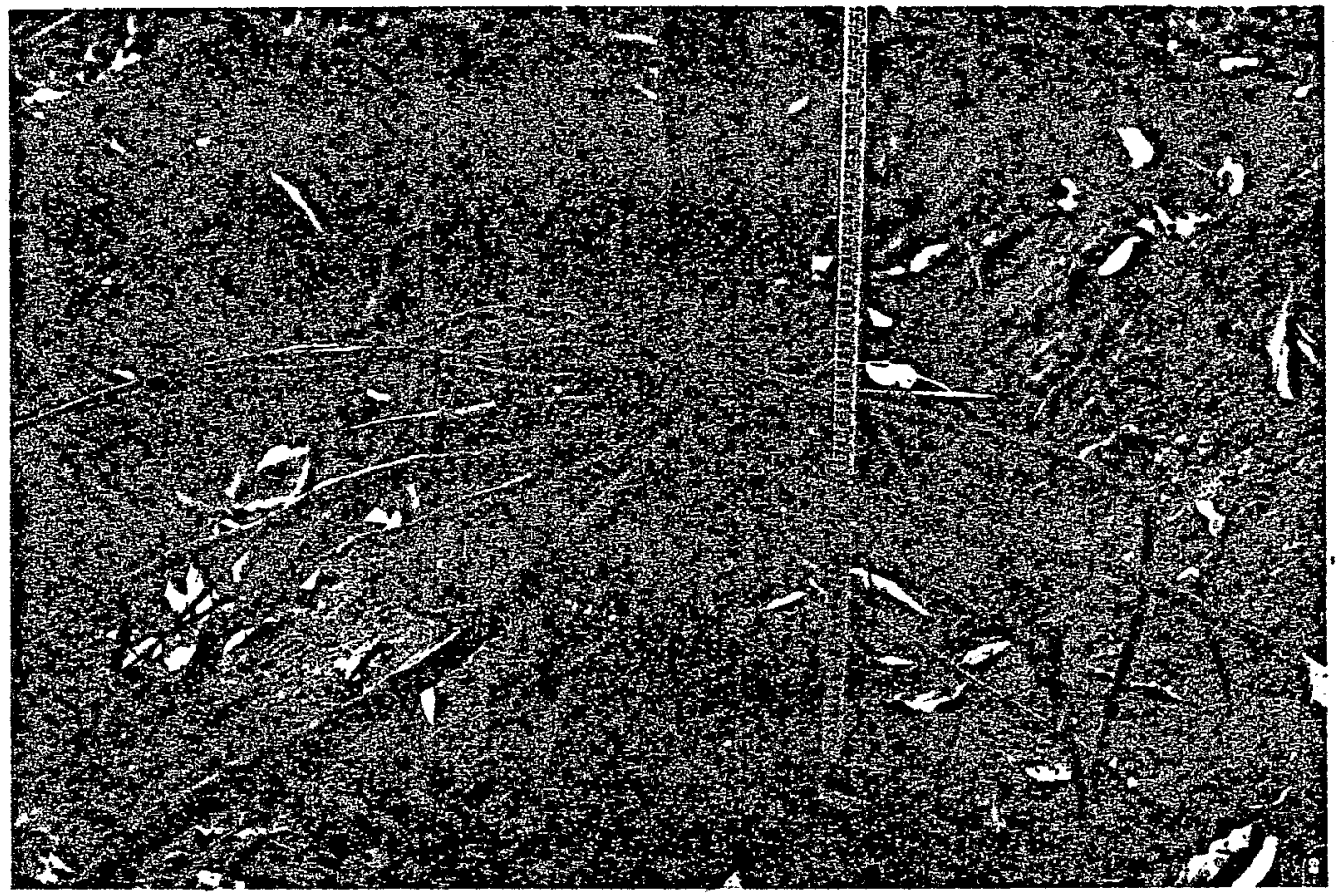

Figura 23. Raízes de árvore morta de Eucalyptus aos 39 meses de idade, oriunda de muda em saco plästico.

urophylla, produzida 
.71

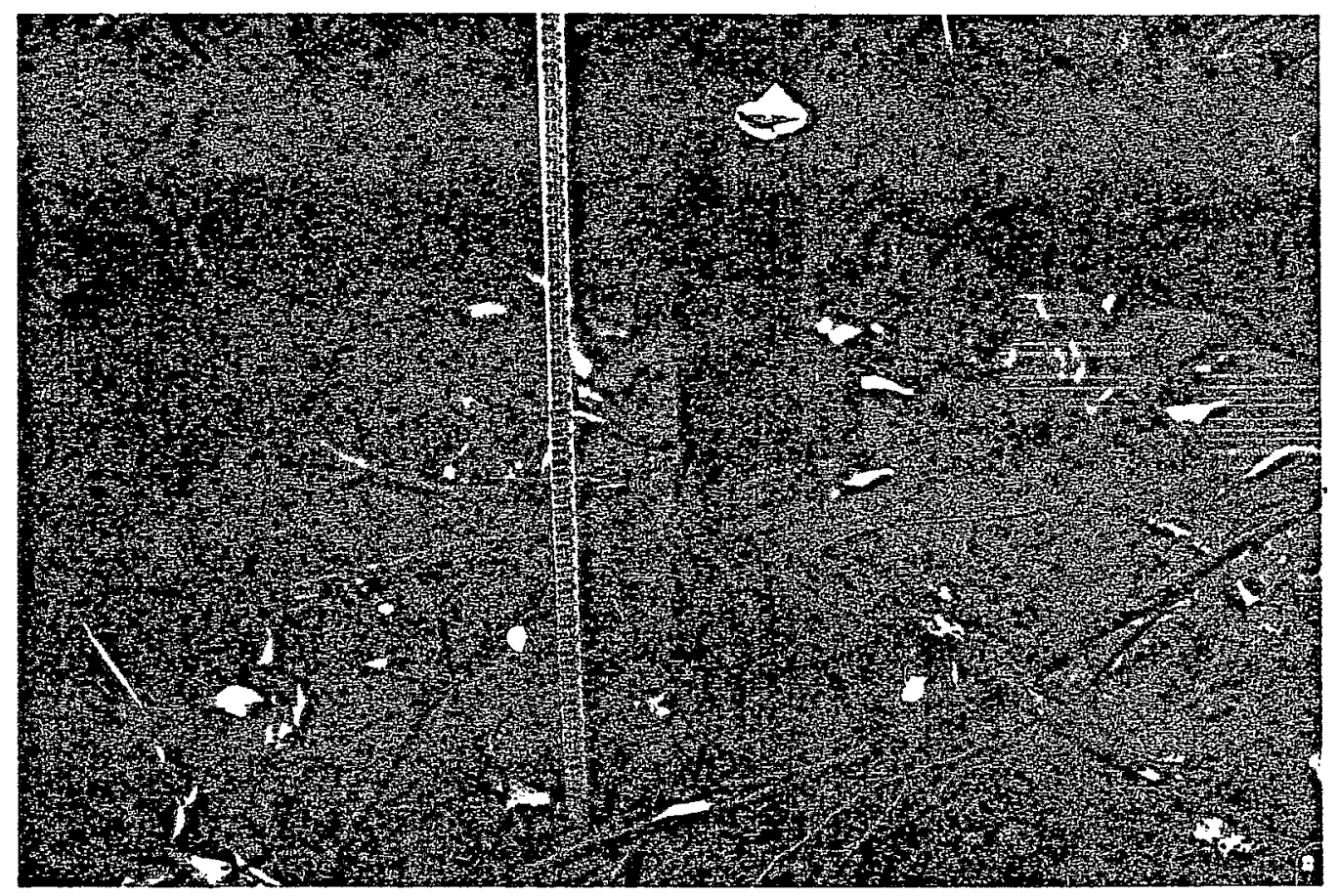

Figura 24. Raízes de árvore morta de Eucalyptus aos 39 meses de idade, oriunda de muda em tubete.

urophylla, produzida 


\section{CONCLUSÕES}

Com base na discussão dos resultados, chegouse às seguintes conclusões:

a) As variações de tipos de substratos, recipientes, tamanho e idade das mudas por ocasião do plantio, não revelaram efeitos diferenciados sobre o crescimento e sobrevivência das plantas.

b) Apesar da menor capacidade de sobrevivência do Eucalyptus grandis, o mesmo apresentou um volume cilíndrico de $202,39 \mathrm{~m}^{3} / \mathrm{ha}$, enquanto que o Eucalyptus urophylla apresentou $164,17 \mathrm{~m}^{3} / \mathrm{ha}$, e mostrou ser uma espécie de maior rusticidade, aos 37 meses de idade.

c) Não houve diferenças nîtidas e preponderantes nas raizes, em função dos tipos de recipientes.

d) A posição competitiva das árvores, mostrou ter maior in fluência sobre a morfologia dos sistemas radiculares. 


\section{REFERÊMCIAS BIBLIOGRÁFICAS}

AGUIAR, I.B. Influência do recipiente na produção de mudas e no desenvolvimento inicial após o plantio no campo, de Eucalyptus grandis Hill ex Maiden e Eucalyptus saligna Smith. Jaboticabal, 1973. 78p. (Doutorado - FMVAJ/UNESP).

AGUIAR, I.B. \& MONOGIOS, G.M. Efeitos de substratos à base de vermiculita na produção de mudas de Eucalyptus citriodo ra Hook em bandejas de isopor. Cientifica, Jaboticabal, $16(1): 133-40,1988$.

ARNOTT, J.T. Roots of planted trees field tour. In: SYMPOSIUM OF THE ROOT FORM OF PLANTED TREES, Victoria, 1978. Proceedings. p.282-5.

BALLONI, E.A. Mortalidade de plantas adultas de Eucalyptus grandis e Eucalyptus saligna na região central do Estado de São Paulo. Série Técnica. IPEF, Piracicaba, $\underline{3}(3)$ : 11521, jun. 1982 .

BLAKE, T. et alii. Early selection of fast-growing Eucalyptus clones and species. IPEF, Piracicaba, (40): 5-14, dez. 1988. 
BOON, J. \& NIERS, H. Use of bark and of sod on cuttings from moorland vegetation in potting mixtures. Acta Horticulturae, (172): 55-65, 1985 .

BRIGATTI, R.A. O tamanho da muda plantada e sua influência no desenvolvimento da planta. Circular Técnica Interna. Champion Papel e Celulose S/A, Mogi Guaçu,: 1-6, 1983.

CAMPINHOS JR., E.; IKEMORI, Y.K.; MARTINS, F.C.G. Determinação do meio de crescimento mais adequado à formação de mudas de Eucalyptus spp. (estaca e semente) e Pinus spp. (se mente) em recipientes plásticos rígidos. In: SIMPÓSIO INTERNACIONAL: METTODOS DE PRODUÇÃO E CONTROLE DE QUALIDADE DE MUDAS FLORESTAIS, Curitiba, 1984. Anais, Curitiba, FUPEF, 1984. p.350-65.

CAMPINHOS JR., E. \& IKEMORI, Y.K. Introdução de nova técnica na produção de muđas de essencias florestais. Silvicultura, São Paulo, $\underline{8}(28): 226-8,1983$.

CARNEIRO, J.G. de A. Determinação do padrão de qualidade de mudas de Pinus taeda para plantio definitivo. Curitiba, 1976. 80p. (Mestrado - Universidade Federal do Paraná).

CARNEIRO, J.G. de A. Variações na metodologia de produção de mudas florestais afetam os parâmetros morfo-fisiológicos que indicam sua qualidade. Curitiba, FUPEF, 1983. 40p.

CARNEIRO, J.G. de A. Efeito da densidade sobre o desenvolvimento de alguns parâmetros morfo-fisiológicos de mudas de Pinus taeda L. em viveiro e após o plantio. Curitiba, 1985. 140p. (Professor - Universidade Federal do Paraná). 
COELHO, L.C.C. Comportamento silvicultural do Eucalyptus gran dis Hill ex Maiden face a classificação pelo tamanho de se mente, de plântula e de muda. Piracicaba, 1984. 118p. (Mestrado - Escola Superior de Agricultura "Luiz de Queiroz"/USP) .

CIA: AGRICOLA E FLORESTAL SANTA BĀRBARA-CAF. Norma técnica para produção de mudas de Eucalyptus. Belo Horizonte, 1980: $6 \mathrm{p}$.

COUTINHO, C.J. \& CARVALHO, C.M. O uso da vermiculita na produção de: mudas florestais. In: ENCONTRO NACIONAL DE REFLORESTADORES, 7, Curitiba, 1983. Anais. p.54-63.

DEER; W.A.; HOWIE, R.A.; ZUSSMAN, J. Rock-forming minerals. 2.ed. London, Iongman Group Itd., 1971. v.3, 270 p.

EIS, S. Natural root forms of western conifers. In: SYMPOSIUM OF THE ROOT FORM OF PLANTED TREES, Victoria, 1978. Proceedings. p.23-7.

ELAM, W.W. \& KOELIING, H.A. Some biological and engineering design aspects of a cooted elay container. In: NORTH AMERICAN CONTAINERIZED FOREST TREE SEEDLING SYMPOSIUM, Denver, 1974. Proceedings. Denver, Great Plains Agricultural Coun cil, 1974. p.136-9.

EMBRAPA-CNPF. Zoneamento ecológico para plantios florestais no Estado do Paraná. Documentos. EMBRAPA, Curitiba, (17): 1-89, 1986.

FAGUNDES, N.B. \& FIALHO, A.A. Problemätica da produção de mu das em essências florestais. Série Técnica. IPEF, Piracicaba, $\underline{4}(13)$ : 25-7; dez. 1987. 
FERNANDES, P.S.; COUTINHO, C.J.; BAENA, E. de S. Produção de mudas de Eucalyptus saligna em bandejas de isopor. Silvicultura, são paulo, $\underline{8}(28): 285-6,1983$.

GOLFARI, L. Comparação de locais entre Austrālia e Brasil ví sando ao plantio de Eucalyptus grandis. . Silvicultura, São Paulo, $3(31): \ldots 406-9$, jul/ago. 1983.

GOMES, F.P. A estatística moderna na pesquisa agropecuária. 3.ed. Piracicaba, POTAFOS, 1987. 162p.

KOZLOWSKI, T.T. Growth and development of trees. New York, Academic Press, 1971. v.2, p.196-250.

KREJCI, K.C.; MARTINS, L.G.E.; LOURENÇO, P.Y. Desenvolvimento do sistema radicular de Eucalyptus spp. sob diferentes condições de solo. Salvador, COPENER, 1986. $24 \mathrm{p}$.

LAUER, D.K. Seedlings size influences early growth of longleaf pine. Tree Planters' Notes, 38(3): 16-7, 1987.

IIEFFERS, V.J. \& ROTHWELL, R.L. Effects of depth of water ta ble and substrate temperature on root and top growth of Picea mariana and Larix laricinu seedings. Canadian Journal of Forest Research, 16(6): 1201-6, dez. 1986.

LYR, H. \& HOFFMAN, G. Growth rates and growth periodicity of tree roots. In: RONIBERGER, J.A.A. \& MIKOLA, P. (ed.). International Review of Forestry Research. New York, Academic press, 1961. v.2, p. 181-236. 
MARQUES, L.C.T. \& YARED, J.A.C. Crescimento de mudas de Didymoponax morototoni (Aublet.) Dence (morototó) em viveiro em diferentes misturas de solo. In: SIMPOSIO INTERNACIONAL: MÉTODOS DE PRODUÇÃO E CONTROLE DE QUALIDADE DE SEMENTES E MUDAS FLORESTAIS, Curitiba, 1984. Anais. Curitiba, FUPEF, 1984. p.149-63.

MONIZ, A.C. Composição química e estrutura dos minerais de argila. In: MONIZ, A.C. (coord.) Elementos de pedologia. São Paulo, Poligono/EDUSP, 1972. p.29-44.

MORAIS, E.J. \& BRUNE, A. Correlação juvenil-adulta em Eucalyptus grandis. Silvicultura, são Paulo, 8(31): 410-11, 1983.

NIELSON, K.F. Roots and shoot temperatures in the plant root and its environment. In: CARSON, E.W. (ed.). Charlottesville, University Press of Virginia, 1974. p.293-333.

NODARI, R.o. et alii. Características de mudas de Schizolobium parahyba (Velloso) Blake, submetidas a diferentes com posições de substrato - fase de viveiro. In: CONGRESSO FLORESTAL ESTADUAL, Nova Prata, 1984. Anais. Nova Prata, 1984. v.2, p.362-73.

ORLANDER, G. \& DUE, K. Location of hydraulic resistence in the soil-plant pathway in seedlings of Pinus sylvestris $L$. grown in peat. Canadian Journal of Forest Research, Ottawa, $16(1): 115-23,1986$. 
PARVIAINEN, J. O desenvolvimento radicular das mudas flores tais no viveiro e no local de plantio. In: SEMINÁRIo DE SEMENTES E VIVEIROS FLORESTAIS, 1, Curitiba, 1981. Anais. Curitiba, FUPEF, 1981. v.2, p.111-30.

POLLARD, D.F.W. Seddling size and age as factors of morphogenesis in white spruce Picea glauca (Moench) Voss buds. Canadian Journal of Forest Research, $\underline{4}(1):$ 97-100, 1974.

PONS, A.L. Fontes e usos da matēria orgânica. IPAGRO Informa, Porto Alegre, (26): 111-47, 1983.

PRADO, D.J.A. Manejo de plantaciones. In: EUCALYPTUS: PRINCIPIOS DE SILVICULTURA Y MANEJO, Santiago, Instituto Florestal, Div. Silvicultura, 1989. p.79-100.

PRITCHETT, W.L. Properties and management of forest soils. New York, John Wiley \& Sons, 1979. p.156-72.

REZENDE, G.C. et alii. Resultados preliminares sobre a influência do tipo de muda no crescimento do Eucalyptus gran dis Hill ex Maiden. Silvicultura, São Paulo, $2(14): 383-4$, 1978.

REZENDE, G.C.; SUITER FILHO, W.; GUSMÃO, A.D. Manejo de mudas de eucalipto em viveiro e seus reflexos sobre o cresci mento após o plantio. In: SIMPÓSIO INTERNACIONAL: MÉTODOS DE PRODUÇÃO E CONTROLE DE QUALIDADE DE SEMENTES E MUDAS FLORESTAIS. Curitiba, 1984. Anais. Curitiba, FUPEF, 1984. p.140-7. 
SANCHES, E.S. et alii. Companhia Guatapará de Celulose e Papel - CELPAG Florestal S/A. In: SIMPOSIO IPEF, I, Piracicaba, 1989. p.73-82.

SCHMIDT - VOGT, H. Morphological and physiological characteristics of planting stock. In: IUFRO WORLD CONGRESS, 17, Kioto, 1984. Proceedings. Kioto, IUFRO, 1984a. p.433-46.

SCHMIDT-VOGT, H. Morpho-physiological quality of forest trees seedlings. In: SIMPÓSIO INTERNACIONAI: MEETODOS DE PRODUÇÃO E CONTROLE DE QUALIDADE DE SEMENTES E MUDAS FLORESTAIS, Curitiba, 1984. Anais. Curitiba, FUPEF, 1984b. p.366-78.

SCHUBERT, G.H. \& ADAMS, R.S. Reforestation practices for conifers in California. Sacramento, Resources Agency, Dept. of Conservation, Division of Forestry, 1971. 357p.

SHIMIZU, J.Y. Seleção fenotipica de Pinus elliottii Engel. var. elliottii no viveiro e seus efeitos no crescimento. Boletim de Pesquisa Florestal. EMBRAPA/URPFCS, Curitiba, (1) : 19-27, 1984 .

SIMÕES, J.W. Problemática da produção de mudas em essências florestais. Série Técnica. IPEF, Piracicaba, 4(13): 1-29, dez. 1987.

SKOLMEN, R.G. \& GOO, D.S. Howemode potting mixes for container planting in the Pacific Islands. Tree Planters' Notes $37(4): 12-6,1986$.

SPURR, S.H. \& BARNES, B.Y. Forest ecology. New York, The Ronald Press, 1973. 571p. 
STAPE, J.L. \& BALLONI, E:A. Sistema de produção de mudas. Americana, Ripasa S/A Celulose e Papel, 1987. 8p.

STAPE, J.L.; BALLONI, E.A.; ZANI FILHO, J. Planejamento técnico em plantas florestais na Ripasa. Série Técnica. IPEF, Piracicaba, 6(18): 1-41, fev. 1989.

STOECKLER, J.H. Seedbed density affects size of 3-0 green ash nursery stock. USDA. Forest Service NC Research Note, (25) : $1-4,1967$.

STURION, J.A. Métodos de produção e técnicas de manejo que influenciam o padrão de qualidade de mudas de essências flo restais. In: SEMINARIO DE SEMENTES E VIVEIROS FLORESTAIS, 1, Curitiba, 1981. Anais. Curitiba, FUPEF, 1981. p.1-26.

WALTERS, G.A. Bare-root and balled-root planting stock of Eu calyptus saligna in survival early growth. "Tree Plants' Notes, 21 (2): 14-26, 1970 .

WALTERS, G.A. Why Hawaii is changing to the dibble-tube systems for reforestation. Journal of Forestry, Washington, 79: 743-5, 1981 .

WALTERS, G.A. \& HORIUCHI, H. Containerized seedlings: key to forestation in Hawaii. In: INTERMOUNTAIN NURSERYMAN'S ASSOCIATION MEETING, Snowmass Village, 1979. Proceedings. $6 \mathrm{p}$.

ZIMMERMAN, M.H. \& BROWN, C.L. Tree structure and function. New York, Springer-Verlag, 1971. 336p. 